\title{
Pensions, Social Security, and the Distribution of Wealth
}

\author{
Arthur B. Kennickell and Annika E. Sundén*
}

October 1997

\begin{abstract}
$\underline{\text { Abstract }}$
For most households, pensions and Social Security are the most important sources of income during retirement, and the promised benefit stream constitutes a sizable fraction of household wealth. This paper uses the Survey of Consumer Finances (SCF) to examine pension coverage, estimate Social Security and pension wealth for U.S. households in 1989 and 1992, and to estimate the effects of pension wealth on non-pension net worth. As expected, the SCF data show that including pensions and Social Security in net worth makes the distribution more even. The analysis of the effects of pension wealth on other types of savings indicates that there is a negative effect of defined benefit plan coverage on nonpension net worth. Surprisingly, the effect of defined contribution plans, such as $401(\mathrm{k})$ plans is insignificant. Social Security also has an insignificant effect on non-pension saving.

*Board of Governors of the Federal Reserve System, 20th/C Street NW, Stop 153, Washington DC 20551. The authors are grateful to Raphael Bostic, Myron Kwast, Martha Starr-McCluer and Brian Surette for helpful comments, and to Kevin Moore and Amy Stubbendick for research assistance. The views presented in this paper are those of the authors alone and do not necessarily reflect the official position of the Board of Governors.
\end{abstract}




\section{Pensions, Social Security, and the Distribution of Wealth}

\section{Introduction}

Approximately half of all U.S. households are covered by employer provided pensions from a current or past job. In addition, almost everyone is covered by Social Security. For most households, pensions and Social Security are the most important sources of income during retirement, and the promised benefit stream constitutes a sizable fraction of household wealth. The purpose of this paper is to examine pension coverage, estimate Social Security and pension wealth for U.S. households in 1989 and 1992, and to estimate the effects of pension wealth on non-pension net worth.

Employer provided pensions are, in principle, of two types: defined benefit (DB) plans and defined contribution (DC) plans. During the last 10 years there has been a shift in new plans from DB plans to DC plans, with a particularly rapid increase in $401(\mathrm{k})$ plans. The growth of DC plans puts more obvious responsibility on the worker to plan for retirement. To gauge the adequacy of retirement savings, it is interesting to examine the distribution of employee contribution rates, the degree of employer matching, and how workers choose to invest their funds.

An important policy issue is how Social Security and pension coverage affect a household's wealth and saving behavior. There is a large empirical literature on the relationship between pensions and savings. However, the findings show mixed estimates of the effects of pensions on savings. An early study by Munnell (1976) found a large offset between pensions and saving, a result also shown by a later study using Canadian data (Dicks-Mireaux and King 1984) and by Avery et. al. (1986) using the 1983 Survey of Consumer Finances. More recently, Bernheim and Scholz (1993) found zero or a negative relationship between savings and pensions, while Venti and Wise (1994) estimated a zero or positive effect of pensions on saving. Finally, Samwick (1994) found a small negative offset. ${ }^{1}$ One reason for the diversity of these results may be the wide range of measurements of pension wealth. We improve on previous studies by using more recent and detailed

${ }^{1}$ Gale (1995) provides a comprehensive summary of the findings of these studies. 
information on pension plan characteristics derived from the Survey of Consumer Finances. A similar range of findings has held in the effects of savings in the form of Individual Retirement Accounts (IRAs). Some authors, notably Poterba, Venti and Wise (1996) have detected positive effects of IRAs on other forms of saving. Engen, Gale and Schultz (1996) have argued persuasively that such results are likely the result of misspecification. In this paper we suggest a new angle on misspecification. We divide IRAs in two groups: accounts more likely to have been earlier roll-overs from pension accounts and accounts that are more likely not to be roll-overs. Estimates suggest that there may be a positive relationship between the first type and the level of other assets, but no significant relationship from other

types of IRAs. One explanation for this result is that the "roll-over IRAs" may be proxing for a higher past level of permanent income associated with a previous job.

The paper is organized as follows: the next section discusses the relationship between pensions and wealth, followed by a description of the data used in the study. The fourth section of the paper presents descriptive statistics on pension coverage between 1989 and 1992. The fifth section discusses pension wealth and its distribution, and the next section examines the effects of pension and Social Security wealth on non-pension saving. The paper concludes with a discussion of the results.

\section{Pensions and Wealth}

In a simple life-cycle model, households save over their working lives and dissave later during retirement. Introducing a pension scheme in this world would simply offset other savings and thereby have no effect on the lifetime wealth distribution. However, this simple result may not hold for three reasons: some pension wealth is not perfectly fungible; differential tax treatment may apply; and some households may have liquidity constraints.

Recent literature has emphasized households' precautionary motives for saving (Carroll 1992; Hubbard, Skinner and Zeldes 1994). Illiquid pensions and Social Security are poor substitutes for precautionary saving. Such illiquidity also hampers households' ability to plan for other contingencies, such as major purchases and bequests. A wide range of research has demonstrated the effects of pensions and Social Security on retirement behavior (Fields and Mitchell 1984). If a pension plan induces workers to retire earlier, and thereby spend a 
longer time in retirement, they will require higher savings (Feldstein 1974). Finally, it has been argued that coverage by a pension plan makes workers realize the need for savings, thereby increasing the level of their savings (Katona 1965). There are also models emphasizing the behavioral aspects of saving, in particular how households create separate mental accounts for different types of assets (Shefrin and Thaler, 1988).

Future pension rights and Social Security benefits constitute an important share of households' assets. McDermed et. al. (1989) find that pensions represent $43 \%$ of net worth for households with pensions. Depending on the offset between pensions and other savings, including pension rights as a part of households' portfolios may result in a more equal wealth distribution. Inclusion of Social Security wealth should also yield a more equal wealth distribution because Social Security benefits replace a higher share of income for low income workers.

\section{Data}

The data in this study come from the Survey of Consumer Finances (SCF) for 1989 and 1992. The SCF is a triennial survey sponsored by the Board of Governors of the Federal Reserve System in cooperation with the Statistics of Income Division of the Internal Revenue Service. The purpose of the SCF is to provide information on the financial characteristics of U.S. households. To this end, the SCF collects very detailed information on households' assets, liabilities and demographic characteristics. ${ }^{2}$

The survey sample size was 3,143 in 1989 and 3,906 in 1992. To provide reliable estimates of highly concentrated assets, the survey oversamples wealthy households. Weights are estimated for each survey case to reflect its representation in the population of all households, and these weights are used in the estimation of general population statistics (Kennickell and Woodburn, 1997).

\footnotetext{
${ }^{2}$ See Kennickell and Starr-McCluer (1994) for a general description of the 1989 and 1992 SCFs.
} 
The SCF data include pension rights from current as well as past jobs. ${ }^{3}$ Data are collected on the types of pension plans, contribution rates, other characteristics of pension plans, expected benefits and retirement age. The Survey includes data on individuals not yet collecting pensions as well as on current recipients. In contrast to other surveys, the SCF data enable us to undertake a detailed analysis of pension wealth in all age groups of the population. ${ }^{4}$

\section{Pension Coverage}

In this section we examine pension coverage from a current or past job. The sample consists of families with a household head age 65 or younger and where either the head or the spouse is working. We focus on this population rather than all households because we believe the process of accumulating and decumulating pension wealth may differ in important ways. Because of the endogenous nature of net worth, this decision may induce some small biases in conclusions about households in the range of normal retirement ages. In a later paper, we plan to look more broadly on the effects of pensions on saving.

\section{Pension Coverage from Current or Past Job}

Table 1 presents descriptive statistics on pension coverage from a current or past job for households in 1989 and 1992 where either the household head or spouse is working and the household head is under age 65. The data show that 61.8 percent of all such households have some kind of pension coverage from a current or past job in 1992. This rate is slightly higher than the coverage rate in 1989. The data indicate a shift from DB coverage to DC coverage between 1989 and 1992. Coverage by a DB plan decreased from 42.2 percent to 40.1 percent over the time period, while coverage by a DC plan increased by a similar

${ }^{3} \mathrm{As}$ in most surveys, missing data are a problem in the SCF. All missing data in the SCF are multiply imputed five times (see Kennickell 1991).

${ }^{4}$ Gustman et. al. (1997) and McGarrry and Davenport (1997) use the Health and Retirement Survey (HRS) to compute pension and Social Security wealth including individuals in the age group 51-61. 
amount from 32.6 percent to 34.2 percent. In both years slightly more than one-third of households who have DB coverage also have DC coverage.

As expected, coverage by any type of pension tends to increase with income and educational attainment. It is interesting to note the substantially lower levels of pension coverage among households with less than a high school degree and for households with annual income less than $\$ 10,000$. This may reflect the fact that workers with little education face fewer opportunities on the labor market, and are employed to a greater extent in jobs less likely to have benefits. Pension coverage increases with age, before declining in the oldest age group. In the 55-64 age group, it is likely that some workers-particularly those with relatively generous pensions-have already retired from their main lifetime jobs and, thus, are excluded from our sample here. There is also evidence that some workers take a second job (bridge job) before completely leaving the labor market, and this second job is less likely to be covered by a pension (Ruhm 1990). If such workers collect lump sum payouts from their pension plan instead of annual benefits at retirement, this may explain the lower coverage rate in the oldest age group. It is also interesting to note that pension coverage increased strongly in the youngest age group between 1989 and 1992, while it has decreased in the group aged 45-54.

DC coverage increased for all age groups except the 35-44 group. Among households with annual income over $\$ 50,000$ a clear shift from DB coverage to DC coverage took place between 1989 and 1992. The share of households with coverage from both a DB and DC plan decreased between 1989 and 1992 among younger households and among households with income less than $\$ 50,000$. Among older households there was a strong increase in secondary coverage by a DC plan.

\section{Pension Coverage from Current Job}

Because active plans may better reflect the choices available to workers, we focus more narrowly on changes in pension coverage in the current job for household heads that were under age 65 and working. As shown in Table 2, about half of household heads are covered by a pension in their current job. Among covered individuals, there has been a clear shift from DB coverage to DC coverage, and a sharp decrease in the share of workers who 
have both DB and DC plans. This change reflects the fact that most new plans are DC plans (Andrews 1992).

DC plans include 401(k)-plans as well as other plans such as thrift, profit-sharing, and stock purchasing plans, Simplified Employee Plans (SEP), defined contribution plans such as TIAA-CREF, money purchase plans, and tax-deferred annuities. Coverage by $401(\mathrm{k})$ plans increased strongly overall from 40.0 percent of working households in 1989 to 49.3 percent in 1992, and it also rose for all groups shown in the table, especially among young workers. Although the median amount accumulated in DC accounts increased from $\$ 5,400$ in 1989 to $\$ 8,500$ in 1992 , it is still low compared to current income. One explanation for such small balances may be that a large share of workers have contributed for a relatively short time since the plans were first introduced-as of 1992, the median time a worker has ben in a DC plan was 5 years. However, it also raises concerns that workers are not contributing enough to their plans.

The fraction of employers and employees contributing to DC plans has remained high over the 1989-1992 period. The share of employees contributing to such plans increased from 76.4 percent to 78.0 percent, while the share of employers contributing remained almost constant. The median total contribution rate by employers and employees increased from 8.0 percent of wages in 1989 to 9.8 percent in 1992. The total contribution rates increase with age and income, and the data show that mean contribution rates are substantially higher than median rates for many groups, indicating a skewed distribution.

One important feature of pension plans that may affect household saving behavior is liquidity. If pension wealth were as liquid as other financial assets, a household might view it as a substitute for other saving. One measure of the liquidity of a pension plan is the degree to which an employee can borrow against the account and/or withdraw funds. The SCF data show that more than half of all individuals covered by a DC plan could borrow against their accounts in 1992, that three-fourths could withdraw funds, and that the percent actually borrowing nearly doubled between 1989 and 1992..$^{5}$ We can conclude that for many households, their DC plans are fairly liquid and can be viewed, as comparable within some

${ }^{5}$ No information is available in the survey on other types of withdrawals. 
bounds, to other savings. ${ }^{6}$

It was noted above that the median amount in DC accounts is quite low. An important issue for retirement income adequacy is not only how much is contributed to the plan but also how the funds are invested. An overly conservative investment strategy may lead to inadequate funds upon retirement but an overly risky strategy close to retirement may have negative consequences for retirement security. The data show that over a quarter of families have most of their funds invested in stocks in 1992, a slight decrease from 1989. However, the share of workers who diversify their funds between stocks and interest-earning assets has increased from 33.6 percent in 1989 to 38.6 percent in 1992.

Over the demographic groups examined, changes in investment patterns are mixed. However, it is interesting to note that individuals with less than a high school degree are more likely to invest in interest-earning assets than the other education groups, and the proportion of the group investing mostly in stock decreased between 1989 and 1992. Individuals with low household income are also more likely to invest in interest-earning assets, and less likely to invest in stock or diversify their portfolios. ${ }^{7}$ One explanation for the observed investment behavior of those education groups might be that such workers are less financially knowledgeable than other groups. However, these groups of workers are more likely to be in low-paying jobs with higher probabilities of unemployment. Given this income uncertainty, it may be a better strategy for these workers to diversify risk and invest in low-risk assets.

\section{Pension Wealth}

In this section we present data on DB and DC pension wealth and Social Security wealth, and we examine how including such assets with other household assets affect the

${ }^{6}$ There may be some complications in withdrawing from or borrowing against pension accounts-for example tax implications, processing delays in receiving the funds and repayment constraints.

${ }^{7}$ The surveys used for this study do not have information on whether the investments are self-directed. The 1995 SCF includes this information and future research will examine how much influence workers have over how their accounts are invested. 
wealth distribution. There are many possible conceptual models of such types of wealth.

For DC plans, the most natural assumption may be to treat the account balance as the present value-parallel to the treatment of IRA and Keogh accounts. This is the practice we adopt here. However, there are other possibilities, including adding the present value of future contributions either by the workers, the employers or both. The argument for DB pensions and Social Security are more complex. The benefits of such plans are a contingent benefit stream to be provided at retirement, with the level of the benefit being a function of wages and years worked. Thus, there is no baseline current value, and a present value calculation depends both on assumptions about future work and plan continuation, as well as assumptions about discount rates, inflation, and post-retirement indexing of benefits. Typically, researchers have taken one of two approaches: estimate the present value of benefits, given that a worker stopped working as of the time of the interview; or compute the present value of benefits, given that the person continues working until the expected retirement age. We have taken the latter approach.

In computing the present value of DB benefits we rely on workers' self-reported measures of expected pension benefits. The SCF collects data on households' expected pension benefits (or replacement rates) and the age at which workers expect to start collecting benefits. It is likely that such self-reports will introduce some measurement error. ${ }^{8}$ However, it is still interesting to estimate pension wealth using self-reported benefits, in part because the self-reported benefits correspond to workers' perception, which should affect households' decisions about saving and portfolio composition. In order to produce a measure of expected benefits, earnings profiles are imputed for each respondent and their spouse/partner in the sample using wage equations estimated from CPS data at the 3-digit occupation level controlling for sex, age, education, race, part-time status and self-employment status.

${ }^{8}$ The 1989 SCF also collected information from employers on the characteristics of pension plans. Using this information and wage earnings profiles for the households in the sample, it is possible to compute the expected benefit. This is likely to introduce less measurement error than using self-reported benefits. This data will be used in a later part of this project. A study by Mitchell (1988) based on similar data from the 1983 SCF showed that workers only have limited information on the characteristics of their pension plans. 
Information about current and past wages is used to align these profiles. Given an adjusted earnings profile, a report on tenure with the firm, expected future labor force participation, expected retirement age, and pension benefits, the expected present value of pension benefits is computed for each worker. Future benefits from past jobs and current payments are added to the figure, and the benefit is discounted using a 3 percent real discount rate and sexspecific survival probabilities. ${ }^{9}$ An outline of the procedure is provided in an appendix.

Using the estimated wage-earnings profiles and reports on labor force participation as inputs to an algorithm provided by the Social Security Administration, we also estimate the expected Social Security benefits for survey respondents and their spouses or partners. ${ }^{10}$ The present value is computed as in the case of DB pensions. The value we use is the net of the present value of future employee contributions. ${ }^{11}$

As shown in table 3, pensions and Social Security constitute a substantial fraction of household wealth. In 1992, overall median pension wealth is approximately five times the size of financial assets for all households and about three-quarters as large as net worth. Social Security wealth is more than twice the median net worth. The first panel of the table indicates that households covered by employer provided pensions have higher assets and net worth than households that are not covered by pensions. As shown in the rest of the table, non-pension net worth is higher for households covered by a pension for all income groups,

${ }^{9}$ This is the real discount rate projected by the Board of Trustees, Federal Old-Age and Survivors Insurance and Disability Insurance Trust Funds (1995). It should be kept in mind that Social Security and pension wealth are calculated under current rules. The Social Security system is projected not to be able to meet its obligation by year 2020 (Board of Trustees, 1995). A reform proposal has been introduced, but there is uncertainty about what Social Security benefits for future generations will be. There is some uncertainty about whether a worker will actually collect his or her private pension. In the case of a DB plan, the firm could terminate the plan or otherwise be unable to fulfill its obligations. The Pension Benefit Guaranty Corporation was established to ensure the benefits from such plans, but the guaranteed payout may fall short of workers' expectations or be limited in other ways.

${ }^{10}$ These benefits are calculated in real terms using 1992-prices.

${ }^{11}$ We ignore the employer's contribution to Social Security for comparability with our treatment of $\mathrm{DB}$ pensions. 
except for the group with incomes above $\$ 100,000$. This result also holds if Social Security wealth is included. One explanation for the difference for the income groups below $\$ 100,000$ may be that workers covered by pensions, on average, have higher paying jobs and a stronger attachment to the labor market than workers who are not covered by pensions. For households in the top income group, the high level of wealth for the group with no pension coverage may reflect the relatively higher prevalence of entrepreneurial wealth among that group. As expected, including pension and Social Security wealth in the measure of net worth increases net worth relatively more for households with incomes less than $\$ 25,000$ than for other groups.

To examine the effects of pensions and Social Security on the distribution of wealth, figures 1-3 show quantile-quantile (Q-Q) plots of various measures of net worth. A Q-Q plot is a graph of the values corresponding to percentile points of one distribution plotted against the values for the corresponding percentile points of another distribution. For example, in figure 1 , the vertical axis corresponds to the distribution of net worth including $401(\mathrm{k})$ accounts (the standard SCF definition of net worth) and the horizontal axis corresponds to the distribution of net worth excluding such accounts. ${ }^{12}$ If the distributions were exactly the same, the plot would lie on the 45-degree line shown in the figure. Because the two distributions differ only by the addition of a positive quantity, it is not surprising that throughout its range the plot lies on or above the 45-degree line. What is interesting in this figure and the rest of the figures, is where the plot deviates from the 45 -degree line. In figure 1 , the plot indicates that the effect of adding 401(k) accounts to other forms of net worth is small, but it is spread broadly over the bottom 99 percent of the wealth distribution. Figure 2 shows a Q-Q plot of net worth including gross pension wealth against the standard SCF definition of net worth. Including pension wealth shifts the distribution upward

${ }^{12}$ To avoid distortions induced by very large values, the data have been subjected to a transformation using the inverse hyperbolic sine $\left(\log \left\{\theta y+\left[\theta^{2} y^{2}+1\right]^{1 / 2}\right\} / \theta\right)$ with a scale parameter $(\theta)$ of 0.0001 . This transformation has the desirable property that, unlike the similar $\log$ transformation, it is defined for values less than or equal to zero. From left to right, the vertical lines in the figure indicate the points corresponding to the $90^{\text {th }}, 99^{\text {th }}$, and $99.5^{\text {th }}$ percentiles of the distributions. 
approximately an equal proportion for most of the bottom 90 percent of the distribution and progressively less above that level. Figure 3 plots net worth including Social Security wealth against the standard definition of net worth. The graph shows the distribution using two measures of Social Security wealth: gross Social Security wealth and Social Security wealth net of employees' contributions. By both Social Security wealth measures, there is a dramatic equalization of the wealth distribution, with a particularly large proportionate increase for the bottom of the wealth distribution. As expected, including both pension wealth and Social Security wealth (figure 4) makes the distribution even more even.

To better examine some of the changes in the wealth distribution and to gauge the role of pensions and Social Security in household finances at different points in the distribution, tables 4 and 5 show various portfolio items and the shares of the total held by the bottom 90 percent of the distributions, the next 9 percent, and the two top $1 / 2$ percent groups for households with heads aged less than $65 .{ }^{13}$ The wealth classification in table 4 is based on the standard SCF net worth definition (including 401(k) accounts), and that in table 5 adds both pension wealth and Social Security wealth. From the Q-Q plots, we expect the inclusion of pension wealth and Social Security wealth to equalize the distribution of wealth, and the data in the tables dramatically underscore this point: Without these retirement assets, the top $1 / 2$ percent of the distribution hold 24 percent of all net worth, but if these assets are included with other wealth, the share plummets to 12 percent. At the same time, the net worth share of the bottom 90 percent rises from 31 percent to 54 percent. Despite these large shifts, some portfolio items stand out for the different groups under both wealth definitions. About 45 percent of all business assets and about 30 percent of publicly traded corporate stocks are held by the top $1 / 2$ percent. At the other end of the distribution, the bottom 90 percent hold the overwhelming majority of pension wealth and Social Security wealth. The assets of the bottom group are also strongly determined by their large share of principal residences and the associated debt.

\footnotetext{
${ }^{13}$ For information on the wealth distribution for the entire population, see Kennickell and Woodburn (1997).
} 


\section{Pensions and Saving}

Theory suggests that if all types of wealth were equally liquid and equally risky, an increase in one type of wealth should be exactly offset in equilibrium by decreases in another type. Clearly, assets vary widely in this regard. For example, many people may consider DB pensions and Social Security less liquid, but safer than a house. The data above suggest that households with pensions have higher levels of non-pension wealth, but this difference could, as noted earlier, be due to other differences.

In order to examine the offset effect of pensions on other savings, we consider a simple multivariate model of non-pension net worth. The empirical model is specified in equation (1):

$$
\mathrm{LNW}_{1}=\alpha_{1} \mathrm{LDB}_{1}+\alpha_{2} \mathrm{LDC}_{\mathrm{t}}+\alpha_{3} \mathrm{LSSEC}_{1}+\alpha_{4} \mathrm{LIRA}_{1}+\beta \mathrm{X}_{\mathrm{t}}+\epsilon_{\mathrm{t}}
$$

The dependent variable is the logarithm of non-pension net worth (LNW) at age t, where age is that of the household head. Net worth is defined for this purpose as the difference between assets and liabilities, excluding consumer durables (other than vehicles) and any retirement assets (assets held in employer-sponsored DB and DC pension plans, and assets accumulated in IRA accounts). It is reasonable to use a broad measure of non-pension wealth since pension wealth is accumulated over long periods of time, providing opportunity to adjust holdings of other assets. The variables used in the analysis are described in detail in table 6.

Retirement wealth is represented by four components: (i) the logarithm of pension wealth from a DB plan (LDBW); (ii) the logarithm of pension wealth from a DC plan (LDCW); (iii) the logarithm of net Social Security wealth (LLSECN) ${ }^{14}$; and (iv) the logarithm of wealth held in an IRA account (LIRA). ${ }^{15}$ Observations with zero value for each of the assets are assigned a value of one. We also include indicator variables for the different

\footnotetext{
${ }^{14}$ In the regression analysis we include Social Security wealth net of pay-roll taxes paid by the worker. workers.

${ }^{15}$ We exclude Keogh accounts from the analysis since they largely cover self-employed
} 
retirement assets to account for ownership. We hypothesize that DB and DC wealth may have different effects on net worth. In a DC plan, the worker receives an account statement and it is possible to know the balance in the account at any given time. In contrast, DB wealth depends on a benefit formula using wage and years of service, and this may be complicated for a worker to estimate. Even if a worker receives a statement of DB plan benefits covering a number of contingencies, the farther a worker is from retirement, the greater the uncertainty about future labor force participation and wages and, thus, greater the uncertainty about the value of such benefits. In order to capture this uncertainty about future benefits, we include an additional factor which incorporates the distance from retirement when computing DB wealth. We include a similar interaction for Social Security wealth. ${ }^{16}$ Some households may not know how their benefits are computed. We include an indicator variable (DKDBW) that takes the value one if a household reported that they do not know their DB benefits and we set the DB wealth to zero for these households. Because missing data are imputed, DKDBW will capture variation attributed to both the respondent's uncertainty and any possible biases in the imputations.

IRAs allow an individual to contribute a maximum of $\$ 2,000$ annually $(\$ 4,000$ for a two-person household) but the since Tax Reform Act of 1986, tax-deductibility of contributions is limited to households without job pensions and with adjusted gross incomes of less than $\$ 50,000$. A worker can also open an IRA to roll-over account balances from a 401(k) plan when changing jobs. In a second specification we divide IRAs in two groups based on the size of the account. LIRAH is the logarithm of IRA wealth in accounts with account balances of $\$ 13,500$ or more, LIRAL includes accounts with balances of less than $\$ 13,500 .^{17}$ Given the maximum allowable contribution to IRAs and the restrictions on taxdeductibility, accounts with lower balances are more likely to be accounts set up by individuals when IRAs where first introduced. Accounts with higher balances may to a larger extent be accounts that have been established to roll-over funds from previous jobs' 401(k)

${ }^{16}$ The reduction factor is computed as $1-\left((\text { years to expected retirement })^{2} / 1000\right)$.

${ }^{17} \mathrm{We}$ inspected the distribution of IRA account balances to determine the cut-off point. Slightly more than 50 percent of IRA-account holders have a balance of less than $\$ 13,500$. 
plans or other pension settlements. One possibility is that the jobs that generated the roll-over accounts differ systematically from the current employer. For example, such past jobs may be associated with a higher permanent income.

The vector $\mathrm{X}$ includes a set of household characteristics to capture aspects of permanent income and life-cycle effects. Net worth is expected to have a positive effect on household income (LHHINC), the age of the household head (AGE), the number of years of education for the household head (EDUC) and the marital status of the household (MARRIED). We also include a variable for the total number of children in the household (KIDS). Also included are variables describing households' ownership of certain assets: an indicator variable for ownership of the principal residence (HOMEOWN), an indicator variable for ownership of investment real estate other than a vacation home (HREALEST), and an indicator variable for ownership of a business (HBUS). Because such risky assets have, on average, a higher rate of return, all these variables are expected to have positive effects on net worth. The final set of variables describes households' savings behavior and attitudes toward saving. We include an indicator variable for whether households save in an unplanned way (NOREGSAV), an indicator variable for whether the household saves regularly (REGSAV), (the excluded category is households who describe themselves as not saving at all). Social Security and pension income constitute a substantial fraction of retirement income for many families. The more adequate a household perceives such future income to be, the less likely they may be to save in other ways. The measure of Social Security and pension adequacy (SSADQI) takes a value from zero to one, and the higher the value the more adequate the household perceives their expected income to be.

If a household expects to have a major financial obligation in the future such as education or health care costs, this may be expected to have a positive effect on the level of net worth. The variable, (FINOBL) is included to indicate whether a household expects any such obligation in the future. We include a variable (HORIZON) to allow for the effects of a household's planning horizon: if a household plans over a relatively short period-whether because of liquidity constraints or choice-one might expect wealth holdings to be more reflective of smaller short-term precautionary needs than longer life-cycle needs. To capture variation of current income from permanent income, we include two indicator variables to 
describe whether households' incomes are lower than normal (NORINCL) or higher than normal (NORINCH). The effects of these variables could work in two ways. If the deviation from permanent income is large enough, wealth is expected to vary in the same direction as the deviation. However, if the deviations are small relative to the stock of wealth, the opposite effect is expected-that is, it would offset the misprediction of wealth on the basis of current income. ${ }^{18}$

The sample includes households with heads age 35-60 who are not self-employed. We exclude younger households since they are still early in their working lives with interruptions for education and more frequent job changes, which makes it more difficult to estimate pension wealth. Among households over age 60, some have already retired and started to draw down their assets. We also exclude households with low or negative net worth-we exclude households with less than $\$ 2,000$ in net worth and/or $\$ 4,000$ in total assets. The remaining sample consists of 949 observations.

The results are presented in table $7 .{ }^{19}$ The model is estimated using ordinary least squares as well as robust methods. In the OLS-specification, having a DB plan has a negative effect on net worth while the size of the DB wealth does not have a significant effect on net worth. The indicator variable for not knowing expected DB benefits is insignificant, indicating that there is no difference in behavior between households who are able to report an estimate of their benefits and those who cannot do so. The estimated coefficients for DC wealth, HAVEDC and LDCW, indicate that there is not a significant effect of DC wealth on net worth, an unexpected result. Social Security wealth also has an insignificant effect on net worth, though at least the negative coefficient is consistent with

${ }^{18}$ The 1995 SCF also includes the value of "normal" income and this will be used in future examination of this question.

${ }^{19}$ As noted earlier, missing data in the SCF are multiply imputed five times. The regression estimates reported in the table account for multiple imputation in the following way. Let $\beta_{i}$ represent the vector of coefficients for a model estimated on implicate " $i$," and let $\sigma_{i}$ represent the associated vector of standard errors. The estimate of the overall $\beta$ is equal to $\Sigma \beta_{i} / 5$ and the estimate of the overall $\sigma$ is given by $\left\{\Sigma \sigma_{i}{ }^{2} / 5+(1+1 / 5) * \Sigma\left(\beta-\beta_{i}\right.\right.$ )$\left.^{2 /} / 4\right\}^{1 / 2}$. See Rubin [1987] for details and Montalto and Sung [1996] for other examples using the SCF. 
expectations; the lack of significance may reflect the relatively small variation in benefits relative to the measurement error in our predictions. The presence of an IRA has a negative and significant effect on non-pension saving but the effect is offset by a positive coefficient on the level of the account-the net effect becomes zero at $\$ 992$ and increases above that level (column 1). We also investigate whether there is a difference in behavior between households with "high" versus "low" account balances in their IRAs. The results (column 2) indicate that for households with "high" account balances, the effect of having an IRA is negative and significant, but the level of the account has a positive and significant effect. On the other hand, for households with "low" account balances, the effect is insignificant. These IRA results lend some support to our hypothesis that there is a difference in savings behavior between the two groups: maybe IRAs with higher account balances are more likely to be linked to a previous employer-sponsored pension and proxy for higher past permanent income.

As expected from a permanent income argument, income and education have a positive and significant effect on net worth. Surprisingly, marital status and the number of children has an insignificant effect on non-pension saving. Perhaps reflecting higher average returns associated with risky assets, the results indicate that households who own their home, investment real estate or a business have higher net worth. Households who consider themselves regular savers have higher net worth than households who do not save regularly or not at all. Although the effect of planning might be attributable to differences in planning horizons, a separate control for one reason of that horizon does not have a significant effect. The perception of the adequacy of Social Security and pension benefits have an insignificant effect on net worth as does a household's expected financial obligations. A lower household income than normal has a positive effect on net worth compared to households with a normal income; one interpretation is that this indicator variable is correcting for the understatement of permanent income by current income in the model. For households with a higher than normal income the effect is insignificant. The models are also estimated with robust methods. The results are similar showing an offset between $\mathrm{DB}$ wealth and non-pension wealth. 


\section{Conclusions}

This paper examined pension coverage and estimated Social Security and pension wealth in the 1989 and 1992 Surveys of Consumer Finances. We also estimated the offset between pensions and non-pension savings. The results indicate that approximately $60 \%$ of all households have pension coverage from a current or past job. Over the time period, there has been a shift from DB coverage to DC coverage, putting more explicit responsibility on the worker to plan for retirement. Although median amounts accumulated in DC accounts have increased during this time period, they remain fairly low. This finding may be explained by the fact that many workers have only contributed for a relatively short time period, but it also raises concerns that workers are not contributing enough to their plans. However, the median contribution rate has increased over the time period. The adequacy of retirement savings is also affected by how the funds are invested. Workers tend to invest their funds in relatively diversified portfolios, with the exception of workers with low income and little education who primarily invest in low risk assets.

Among families with income of $\$ 50,000$ or less, those with pension coverage have higher net worth than families without pension coverage. For higher-income families, net worth is lower for families with pension coverage than it is for families without pension coverage. Overall, the results indicate that Social Security and pensions constitute a substantial fraction of household wealth, comprising $82 \%$ of total net worth. As expected, the SCF data show that including pensions and Social Security in net worth dramatically equalizes the distribution of net worth.

The analysis of the effects of pension wealth on other types of savings indicates that there is a negative effect of DB plan coverage on non-pension net worth. On the other hand, the effect of DC plans, such as 401(k) plans, is insignificant, a surprising result. Social Security also has an insignificant result on non-pension saving, maybe reflecting households' uncertainty about the level of future Social Security benefits. Overall, ownership of IRAs has a negative effect on holdings of non-pension wealth, but the offset is positive for accounts over about $\$ 1,000$. It appears that this effect is driven almost entirely by relatively large account holders: one possible explanation of this difference is that the large accounts maybe more likely to be rollovers from past jobs with higher associated levels of permanent income. 


\section{References}

Andrews, Emily S., "The Growth and Distribution of 401(k) Plans" in Trends in Pensions, Turner, John A. and Daniel J. Beller, (eds.) U.S. Department of Labor, Washington DC: U.S. Government Printing Office, 1992.

Avery, Robert B., Gregory E. Ellihausen, and Thomas A. Gustafson, Pensions and Social Security in Household portfolios: Evidence from the 1983 Survey of Consumer Finances, Federal Reserve Board Working Paper, 1985

Bernheim, B. Douglas, and John Karl Scholz, "Private Saving and Public Policy" in James M. Poterba, (ed), Tax Policy and the Economy, Vol 7, Cambridge: MIT Press 1993, pp 73-110.

Board of Trustees, Federal Old-Age and Survivors Insurance and Disability Insurance Trust Funds, 1995 Annual Report, Washington: U.S. Government Printing Office, 1995.

Carroll, Christopher, "The Buffer Stock Theory of Saving: Some Macroeconomic Evidence." Brookings Papers on Economic Activity, 1992, 2, pp 61-156.

Dicks-Mireaux, Louis, and Mervyn King, "Pension Wealth and Household Savings: Tests of Robustness," Journal of Public Economics, 23, 1984, pp 115-139.

Engen, Eric, William Gale and John Karl Scholz, "The Illusory Effects of Saving Incentives on Saving", Journal of Economic Perspectives, 10, 1996, pp 113-138.

Feldstein, Martin, "Social Security, Induced Retirement, and Aggregate Capital Accumulation", Journal of Political Economy, 82, September/October, 1974, pp 905 926.

Fields, Gary S. and Olivia S. Mitchell, Retirement, Pensions and Social Security, Cambridge: MIT Press, 1984.

Gale, William G. The Effects of Pensions on Wealth: A Re-Evaluation of Theory and Evidence, The Brookings Institution, 1995, mimeo.

Gustman, Alan, Olivia Mitchell, Andrew Samwick and Thomas Steinmeier, Pensions and Social Security Wealth in the Health and Retirement Study, NBER Working Paper 5912, February 1997.

Hubbard, R. Glenn, Jonathan Skinner, and Stephen Zeldes. "The Importance of Precautionary Saving Motives in Explaining Individual and Aggregate Saving." Carneige-Rochester Conference Series on Public Policy, June 1994, 40, pp 59-125. 
Katona, George, Private Pensions and Individual Saving, Ann Arbor: University of Michigan Press, 1965.

Kennickell, Arthur B., "Imputation of the 1989 Survey of Consumer Finances: Stochastic Relaxation and Multiple Imputation," Proceedings of the Section on Survey Research Methods, 1991 Annual Meetings of the American Statistical Association.

Kennickell, Arthur B. and Martha Starr-McCluer. "Changes in Family Finances from 1989 to 1992: Evidence from the Survey of Consumer Finances", Federal Reserve Board Bulletin, 1994, October: 861-882.

Kennickell, Arthur B., and R. Louise Woodburn, Consistent Weight Design for the 1989. 1992 and 1995 SCFs and the Distribution of Wealth, Board of Governors of the Federal Reserve System, Washington DC, August 1997.

McDermed, Ann A., Robert L. Clark, and Steven G. Allen, "Pension Wealth, Age-Wealth Profiles, and the Distribution of Net Worth" in The Measurement of Saving, Investment, and Wealth, eds. R. Lipsey and Helen Stone, Chicago: The University of Chicago Press, 1989.

McGarry, Kathleen, and Andrew Davenport, Pensions and the Distribution of Wealth, NBER Working Paper No. 6171, September 1997.

Mitchell, Olivia S., "Worker Knowledge of Pension Provisions," Journal of Labor Economics, 1988, 6(1):21-39.

Montalto, Catherine Phillips and Jaimie Sung, "Multiple Imputation in the 1992 Survey of Consumer Finances," Financial Counseling and Planning, 1996, Volume 7, pp. 133146.

Munnell, Alicia H., "Private Pensions and Saving: New Evidence", Journal of Political Economy, 84, 1976, 1013-1032.

Poterba, James M, Steven F. Venti and David A. Wise, "How Retirement Saving Program Increase Saving", Journal of Economic Perspectives, 10, 1996, pp 91-112.

Rubin, Donald B., Multiple Imputation for Nonresponse in Surveys, New York, John Wiley Sons, 1987.

Ruhm, Christopher J. "Bridge Jobs and Partial Retirement", Journal of Labor Economics, 1990, 8(4): 482-501.

Samwick, Andrew A., The Limited Offset Between Pension Wealth and Other Private Wealth: Implications of Buffer-Stock Saving, Mimeo, December 1994. 
Shefrin, Hersh M., and Richard H. Thaler, "The Behavioral Life-Cycle Hypothesis", Economic Inquiry, October 1988, pp 609-643.

Turner, John A. and Daniel J. Beller, (eds.) Trends in Pensions 1992, U.S. Department of Labor, Washington DC: U.S. Government Printing Office, 1992.

Venti, Steven F. and David A. Wise, The Wealth of Cohorts: Retirement Saving and the Changing Assets of Older Americans, NBER Working Paper no 4600, Cambridge, 1993. 
Table 1: $\quad$ Pension Coverage from Current or Past Job, 1989 and 1992 (\%)

Household head or spouse working, household head younger than age 65

\begin{tabular}{|c|c|c|c|c|c|c|c|c|}
\hline \multirow[b]{2}{*}{ Year } & \multicolumn{2}{|c|}{$\begin{array}{l}\text { Households with } \\
\text { some pension } \\
\text { coverage }\end{array}$} & \multicolumn{2}{|c|}{$\begin{array}{l}\text { Households with } \\
\text { DB-coverage }\end{array}$} & \multicolumn{2}{|c|}{$\begin{array}{l}\text { Households with } \\
\text { DC-coverage }\end{array}$} & \multicolumn{2}{|c|}{$\begin{array}{l}\text { Households with } \\
\text { DC-coverage } \\
\text { among } \\
\text { households with } \\
\text { DB-coverage }\end{array}$} \\
\hline & 1989 & 1992 & 1989 & 1992 & 1989 & 1992 & 1989 & 1992 \\
\hline All households & 60.4 & 61.8 & 42.2 & 40.1 & 32.6 & 34.2 & 38.2 & 35.8 \\
\hline 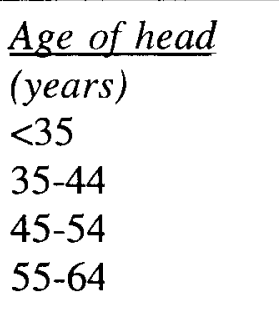 & $\begin{array}{l}43.5 \\
70.0 \\
75.2 \\
61.5\end{array}$ & $\begin{array}{l}50.2 \\
67.2 \\
70.3 \\
64.2\end{array}$ & $\begin{array}{l}25.6 \\
50.9 \\
56.2 \\
46.1\end{array}$ & $\begin{array}{l}28.3 \\
43.5 \\
49.3 \\
46.8\end{array}$ & $\begin{array}{l}26.7 \\
39.8 \\
36.9 \\
26.0\end{array}$ & $\begin{array}{l}28.6 \\
37.3 \\
38.6 \\
33.7\end{array}$ & $\begin{array}{l}40.4 \\
41.0 \\
38.0 \\
28.6\end{array}$ & $\begin{array}{l}29.9 \\
36.2 \\
39.8 \\
37.1\end{array}$ \\
\hline $\begin{array}{l}\frac{H H \text { lncome }}{(\$ \text { thousand, }} \\
\frac{\text { 1992-dollars })}{<10} \\
10-24.9 \\
25-49.9 \\
50-99.9 \\
>100\end{array}$ & $\begin{array}{l}17.4 \\
36.7 \\
68.5 \\
80.0 \\
76.2\end{array}$ & $\begin{array}{l}14.1 \\
42.6 \\
70.4 \\
81.1 \\
77.7\end{array}$ & $\begin{array}{l}11.4 \\
25.5 \\
45.7 \\
59.8 \\
54.3\end{array}$ & $\begin{array}{r}9.7 \\
25.8 \\
45.1 \\
55.1 \\
51.3\end{array}$ & $\begin{array}{r}7.4 \\
15.9 \\
35.2 \\
46.0 \\
56.9\end{array}$ & $\begin{array}{r}2.6 \\
18.8 \\
35.6 \\
52.1 \\
57.8\end{array}$ & $\begin{array}{l}16.1 \\
23.6 \\
31.7 \\
46.1 \\
67.3\end{array}$ & $\begin{array}{r}0.0 \\
14.7 \\
28.1 \\
49.7 \\
65.0\end{array}$ \\
\hline $\begin{array}{l}\frac{\text { Education }}{\text { Less than HS }} \\
\text { High School } \\
\text { College }\end{array}$ & $\begin{array}{l}46.0 \\
59.7 \\
67.0\end{array}$ & $\begin{array}{l}37.9 \\
59.9 \\
71.2\end{array}$ & $\begin{array}{l}33.5 \\
42.0 \\
45.9\end{array}$ & $\begin{array}{l}23.8 \\
37.8 \\
47.8\end{array}$ & $\begin{array}{l}14.3 \\
32.3 \\
40.4\end{array}$ & $\begin{array}{l}16.4 \\
31.7 \\
42.5\end{array}$ & $\begin{array}{l}13.5 \\
38.2 \\
45.4\end{array}$ & $\begin{array}{l}17.2 \\
32.0 \\
42.3\end{array}$ \\
\hline
\end{tabular}

Source: Survey of Consumer Finances 


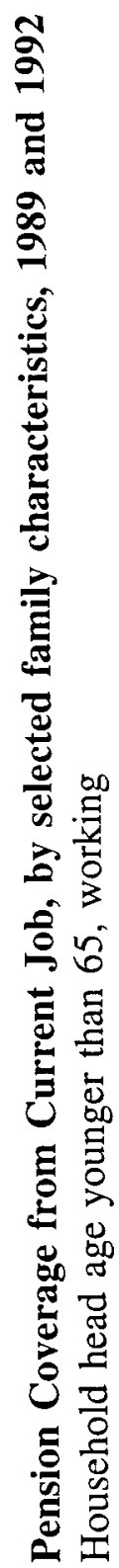

\begin{tabular}{|c|c|c|c|c|c|}
\hline \multirow{2}{*}{ 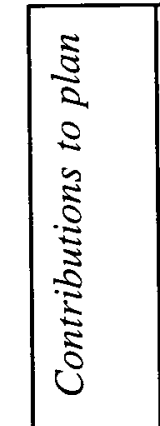 } & 气ั้ & 古 & 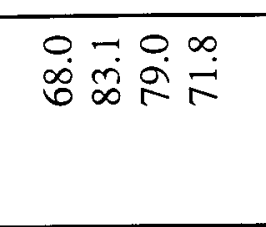 & 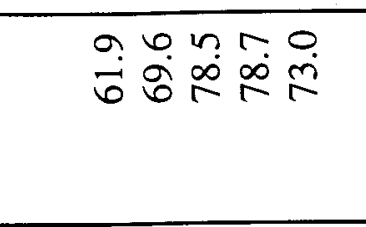 & 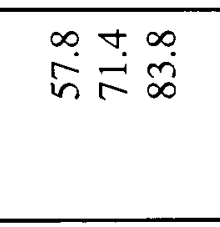 \\
\hline & 產 & 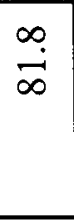 & 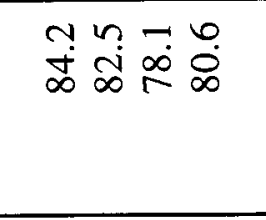 & 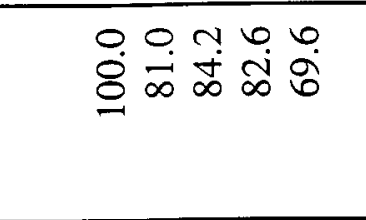 & 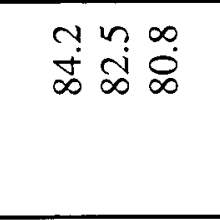 \\
\hline \multicolumn{2}{|c|}{ 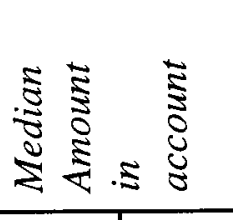 } & 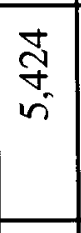 & 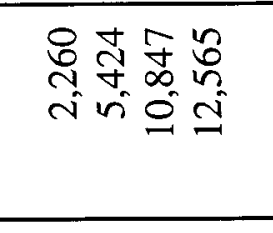 & 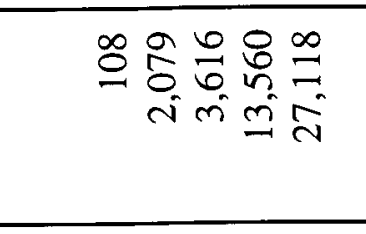 & 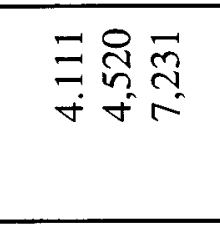 \\
\hline \multirow{2}{*}{ 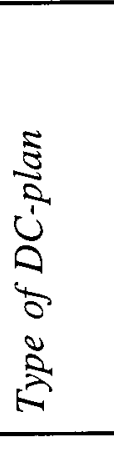 } & 气ั้ & $\begin{array}{l}0 \\
\dot{\theta}\end{array}$ & 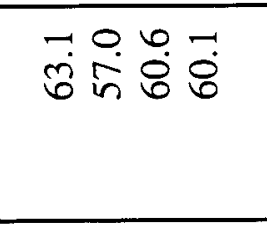 & 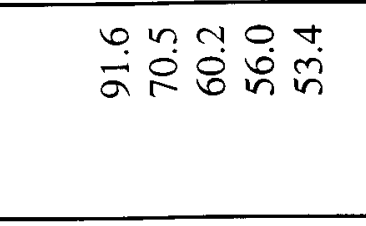 & 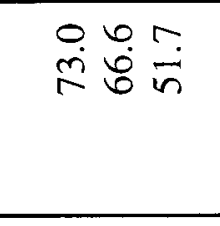 \\
\hline & 言 & $\dot{\dot{\sigma}}$ & 官宇芦鬲商 & 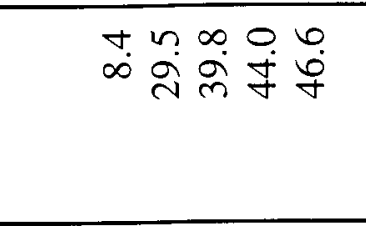 & 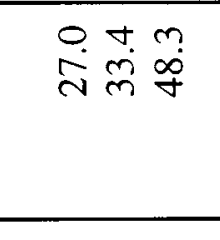 \\
\hline \multirow{3}{*}{ 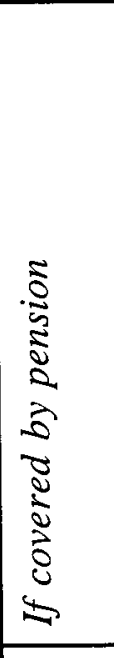 } & 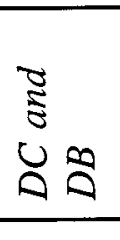 & $\frac{n}{i n}$ & 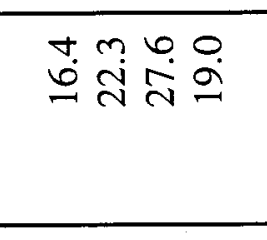 & 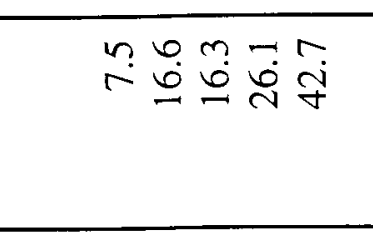 & 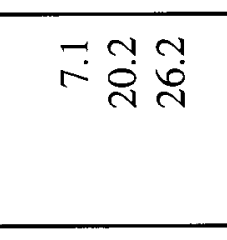 \\
\hline & $\begin{array}{l}\text { U } \\
\vdots \\
\Xi \\
\end{array}$ & $\stackrel{m}{m}$ & 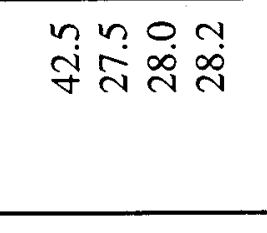 & 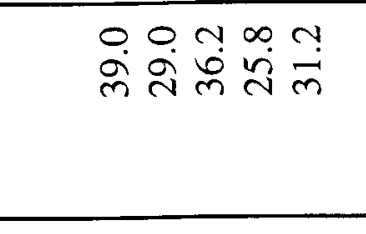 & 守尚品 \\
\hline & हิ: & 我 & 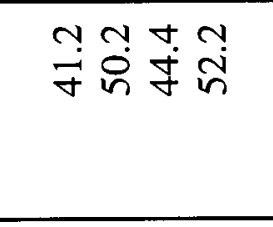 & 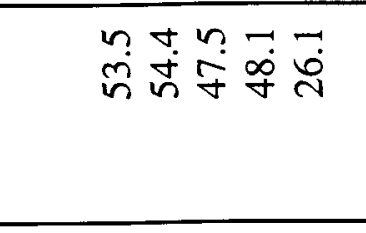 & 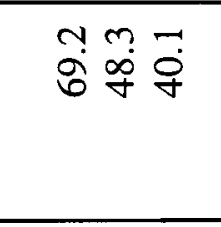 \\
\hline \multirow[t]{2}{*}{ हેँ } & & $\stackrel{s}{n}$ & कृ & 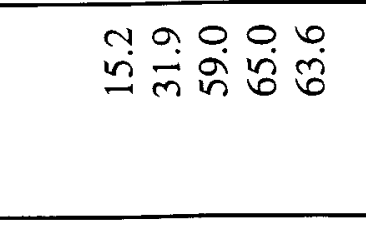 & 总葍落 \\
\hline & & 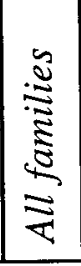 & 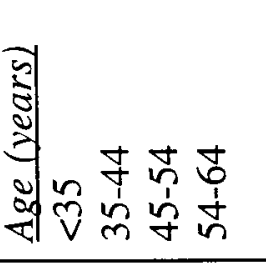 & 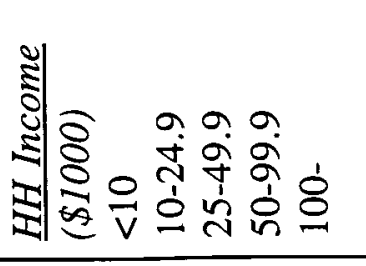 & 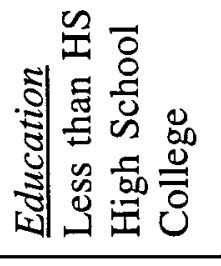 \\
\hline
\end{tabular}




\begin{tabular}{|c|c|c|c|c|c|}
\hline \multirow{4}{*}{ 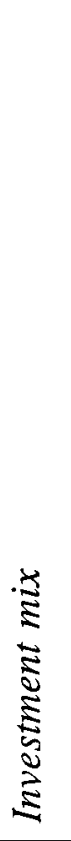 } & $\frac{\grave{\Xi}}{\vdots}$ & $\stackrel{n}{+}$ & $\ddot{\sim} \stackrel{\infty}{*} \stackrel{0}{\sim} \tilde{c}$ & $\stackrel{0}{0} \ddot{m} \ddot{m} \dot{m}$ & نे \\
\hline & 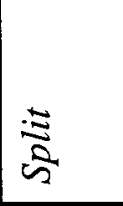 & mे & $\begin{array}{l}\mathfrak{m} g \\
m \dot{m} \\
m\end{array}$ & 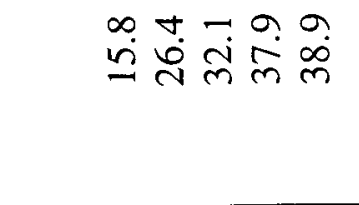 & $\overrightarrow{\dot{\Xi}} \dot{m}$ \\
\hline & 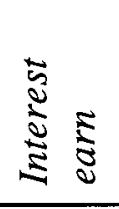 & $\ddot{m}$ & 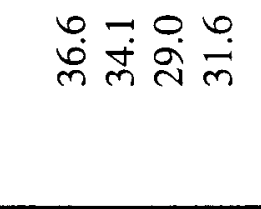 & mị & 뮬ㄹ \\
\hline & $\frac{\pi}{\tilde{z}}$ & $\begin{array}{l}o \\
\infty \\
\stackrel{\sim}{N}\end{array}$ & 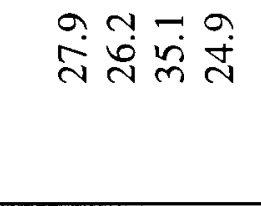 & 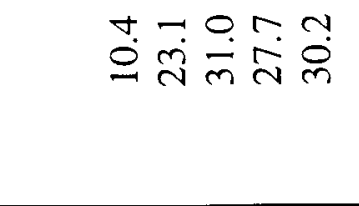 & 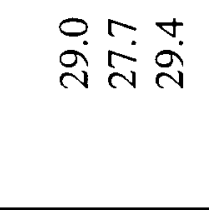 \\
\hline \multicolumn{2}{|c|}{ 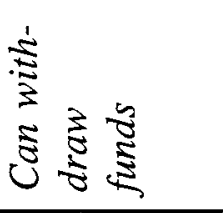 } & $\stackrel{1}{\infty}$ & 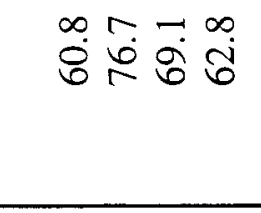 & 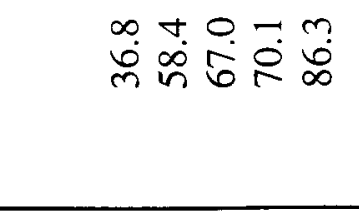 & ช் \\
\hline \multicolumn{2}{|c|}{$\frac{5}{3}$} & $\vec{r}$ & $\stackrel{\infty}{i} \hat{i} \dot{i}$ & 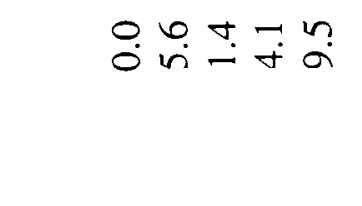 & 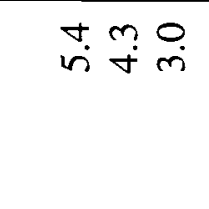 \\
\hline \multicolumn{2}{|c|}{ 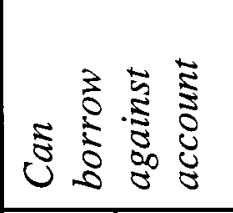 } & $\stackrel{r}{\infty}$ & 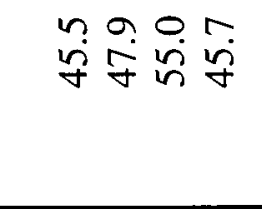 & 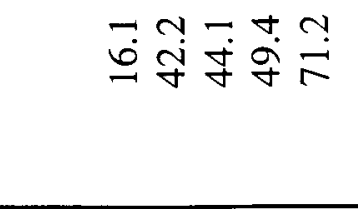 & 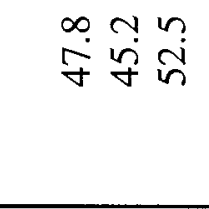 \\
\hline \multirow{2}{*}{ 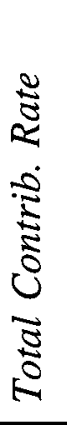 } & 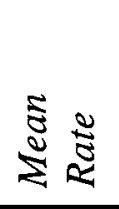 & $\stackrel{1}{0}$ & nڤ் & $\stackrel{\circ}{=} \stackrel{\circ}{=} \stackrel{0}{=} \stackrel{\infty}{=}$ & $\ddot{n} \stackrel{\sim}{0} \stackrel{\infty}{0}$ \\
\hline & 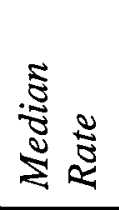 & $\stackrel{\circ}{\infty}$ & 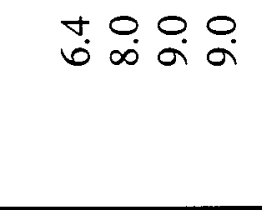 & 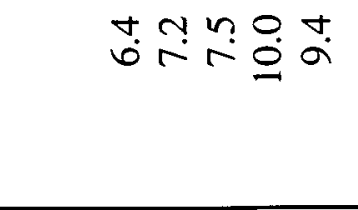 & $\stackrel{\circ}{0} \stackrel{0}{\infty} \stackrel{0}{\infty}$ \\
\hline & & 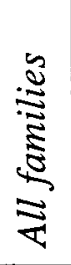 & 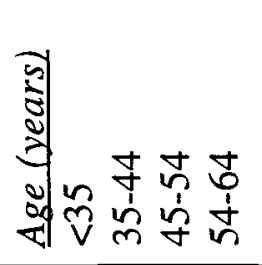 & 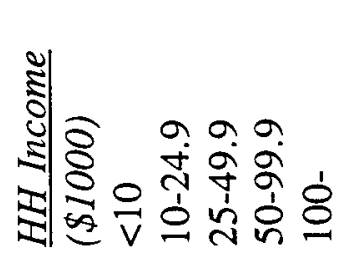 & 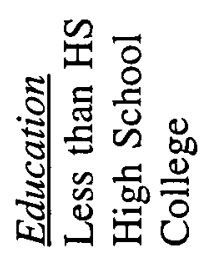 \\
\hline
\end{tabular}




\begin{tabular}{|c|c|c|c|c|c|}
\hline \multirow{2}{*}{ 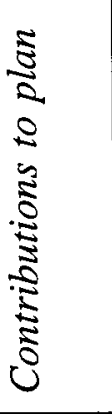 } & 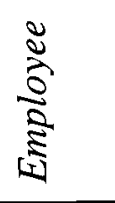 & $\underset{\infty}{\infty}$ & 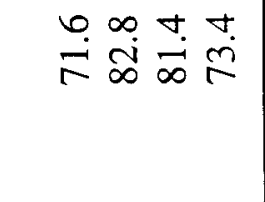 & 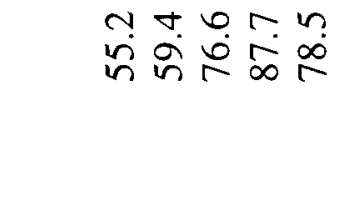 & 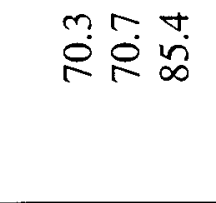 \\
\hline & $\frac{\grave{2}}{\frac{2}{2}}$ & $\stackrel{?}{\infty}$ & 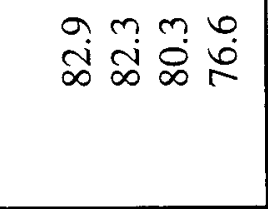 & 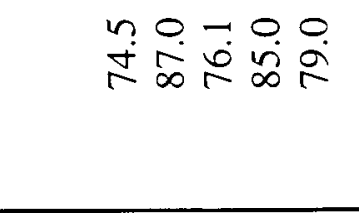 & $\begin{array}{l}\infty \text { 누 } \\
\infty \\
\infty \\
\infty\end{array}$ \\
\hline \multicolumn{2}{|c|}{ 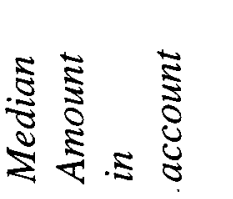 } & $\begin{array}{l}8 \\
\infty \\
\infty\end{array}$ & 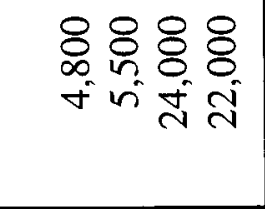 & 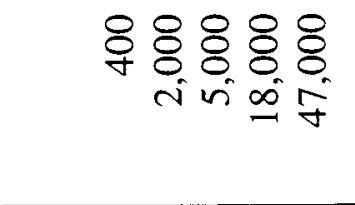 & 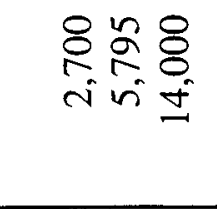 \\
\hline \multirow{2}{*}{ 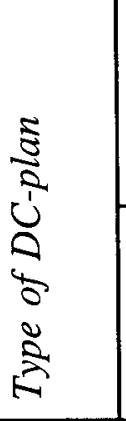 } & $\frac{2}{2}$ & $\ddot{\circ}$ & 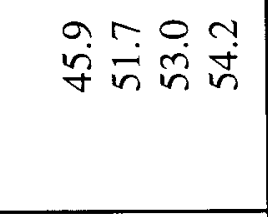 & 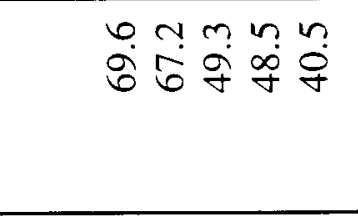 & 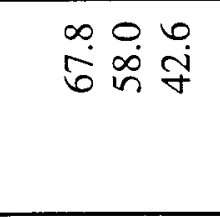 \\
\hline & $\frac{8}{2}$ & $\stackrel{m}{q}$ & 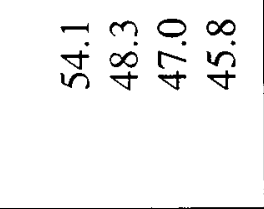 & 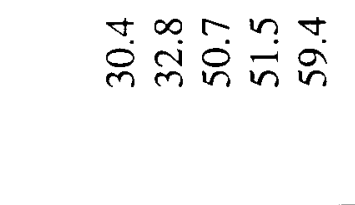 & $\begin{array}{l}\text { N } \\
\text { N } \\
\text { N }\end{array}$ \\
\hline \multirow{3}{*}{ 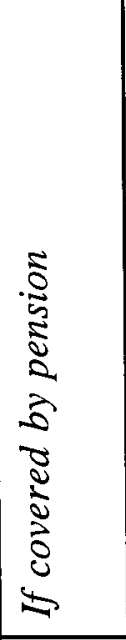 } & $\begin{array}{l}\stackrel{\Xi}{\Xi} \\
\bigcup \emptyset\end{array}$ & $\begin{array}{l}\infty \\
\ddot{n}\end{array}$ & 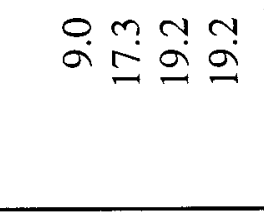 & 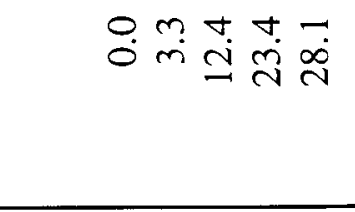 & 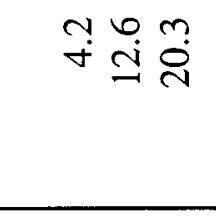 \\
\hline & $\begin{array}{l}\frac{0}{6} \\
\frac{2}{3} \\
0\end{array}$ & $\frac{⿱ 亠}{\nabla}$ & m̊ํ & $\begin{array}{l}\infty \\
\dot{\sim} \\
\dot{\sim} \\
\dot{q}\end{array}$ & ㅁํㅇ \\
\hline & $\begin{array}{l}\infty \\
\frac{1}{5} \\
0\end{array}$ & $\stackrel{\text { भे }}{\text { भे }}$ & 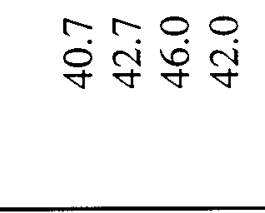 & 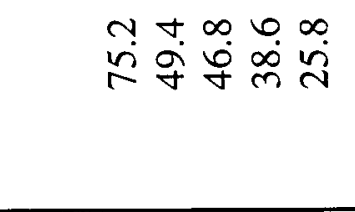 & ت் \\
\hline \multirow{2}{*}{\multicolumn{2}{|c|}{ ठ̀े }} & $\ddot{n}$ & $\begin{array}{l}\forall \\
\dot{q} \\
\dot{y}\end{array}$ & i & $\begin{array}{l}a+\infty \\
\dot{d}\end{array}$ \\
\hline & & 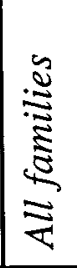 & 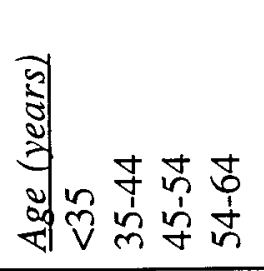 & 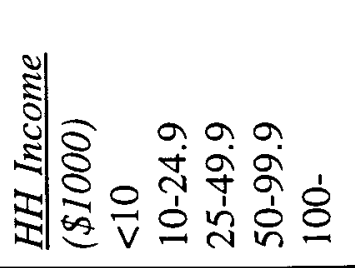 & 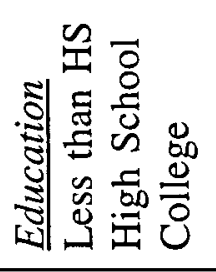 \\
\hline
\end{tabular}




\begin{tabular}{|c|c|c|c|c|c|}
\hline \multirow{4}{*}{ 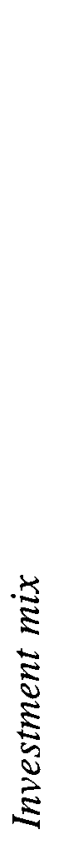 } & 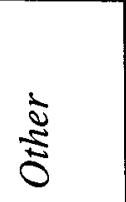 & $\stackrel{n}{=}$ & $\begin{array}{l}\infty \\
\dot{r} \tilde{0}\end{array}$ & 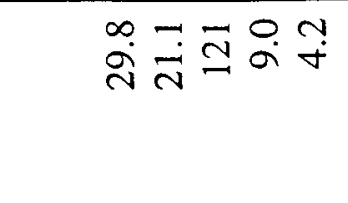 & $\begin{array}{l}\infty \\
\sim \\
\sim\end{array}$ \\
\hline & $\frac{:}{5}$ & $\begin{array}{l}\infty \\
\infty \\
\infty\end{array}$ & 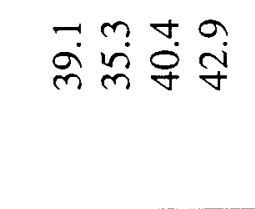 & 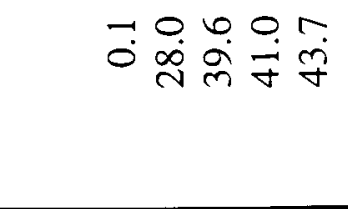 & 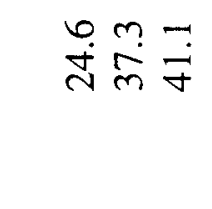 \\
\hline & 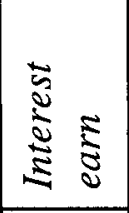 & $\ddot{n}$ & 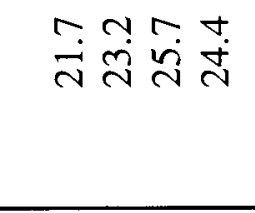 & 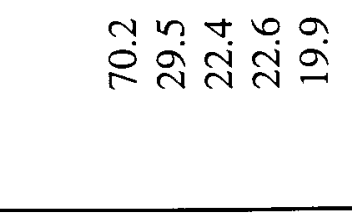 & 莳 \\
\hline & $\frac{w}{\grave{c}}$ & $\stackrel{\forall}{\dot{0}}$ & 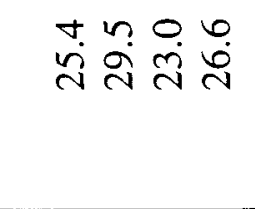 & 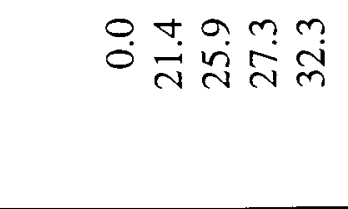 & ๓ं \\
\hline \multicolumn{2}{|c|}{ 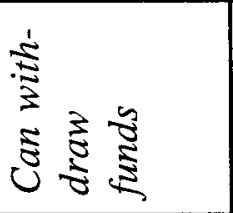 } & $\ddot{n}$ & 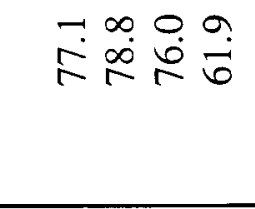 & 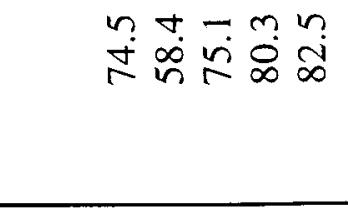 & 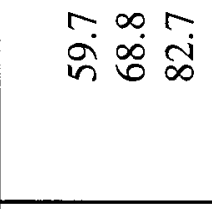 \\
\hline \multicolumn{2}{|c|}{$\begin{array}{c}5 \\
\vdots \\
0 \\
\vdots \\
0 \\
2\end{array}$} & $\underbrace{\infty}_{0}$ & 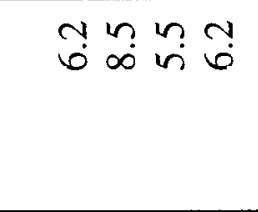 & 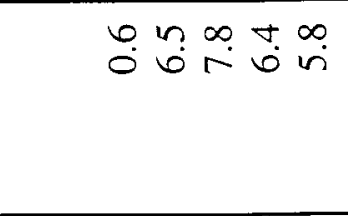 & 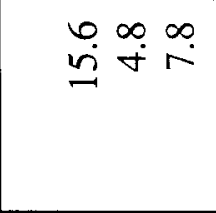 \\
\hline \multicolumn{2}{|c|}{ 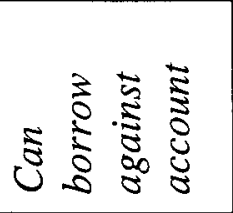 } & $\begin{array}{l}\infty \\
i \\
i\end{array}$ & 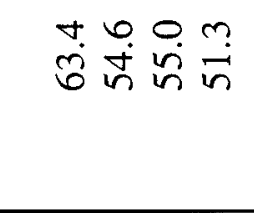 & 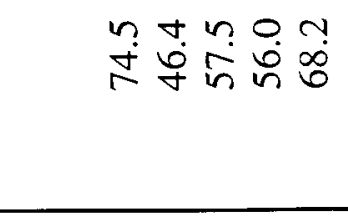 & $\stackrel{\infty}{\infty} \frac{0}{n}$ \\
\hline \multirow{2}{*}{ 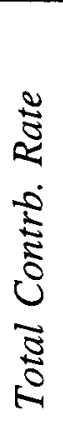 } & 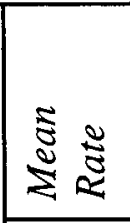 & 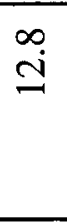 & 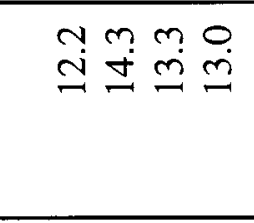 & vị & 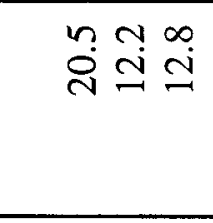 \\
\hline & 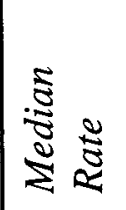 & $\stackrel{\infty}{a}$ & å & 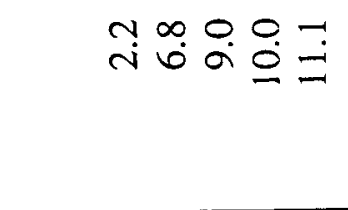 & $\begin{array}{l}\text { o } 000 \\
\text { i் }\end{array}$ \\
\hline & & 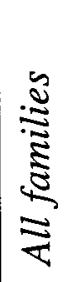 & 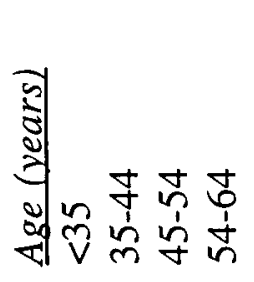 & 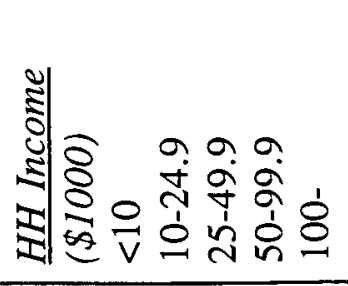 & 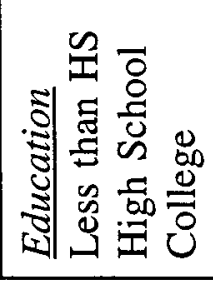 \\
\hline
\end{tabular}




\begin{tabular}{|c|c|c|c|c|c|}
\hline 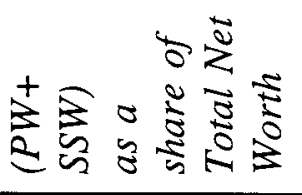 & $\stackrel{\infty}{\infty}$ & $\begin{array}{l}\dot{D} \\
0 \\
0\end{array}$ & $\stackrel{\overbrace{}}{0}$ & & 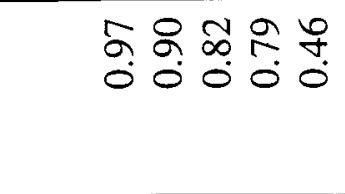 \\
\hline 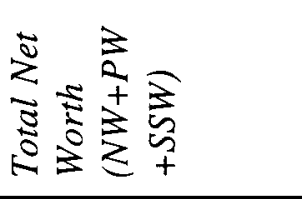 & 吕 & $\hat{\nabla}$ & $\overrightarrow{\ddot{\theta}}$ & & 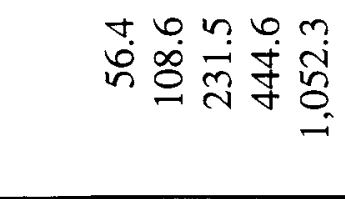 \\
\hline 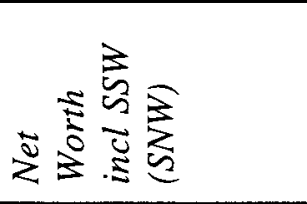 & $\begin{array}{l}\infty \\
\infty \\
\stackrel{\infty}{n} \\
\sim\end{array}$ & $\stackrel{a}{\grave{a}}$ & है & & 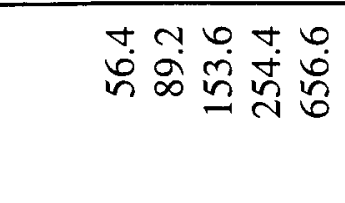 \\
\hline 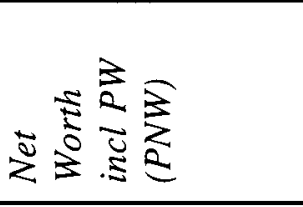 & & $\stackrel{\Re}{\tilde{D}}$ & $\vec{\infty}$ & & 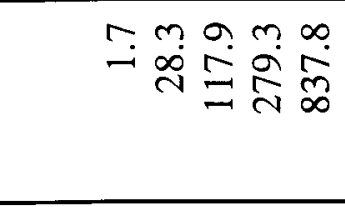 \\
\hline 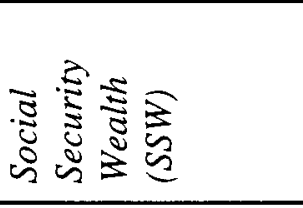 & $\begin{array}{l}n \\
\ddot{g}\end{array}$ & $\stackrel{\Xi}{\Xi}$ & $\underset{\infty}{\infty}$ & & 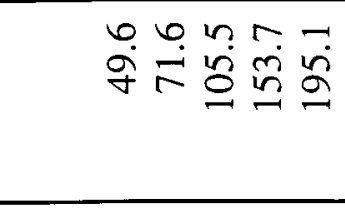 \\
\hline 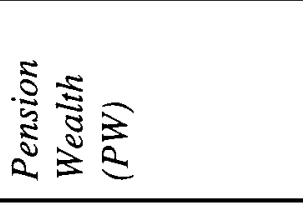 & $\stackrel{i}{m}$ & $\stackrel{\Xi}{\dot{J}}$ & $\stackrel{\circ}{\circ}$ & & 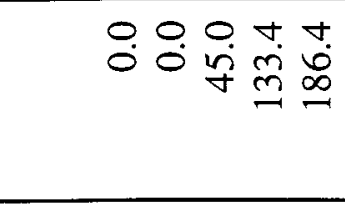 \\
\hline 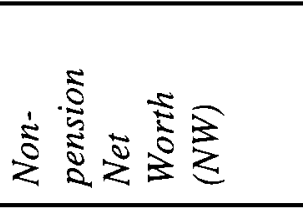 & $\ddot{q}$ & $\begin{array}{l}0 \\
\ddot{n}\end{array}$ & $\vec{\infty}$ & & 을욜 芦范守 \\
\hline 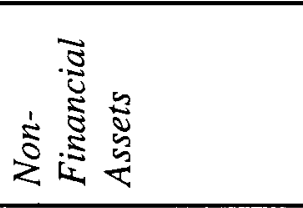 & $\stackrel{\infty}{a}$ & $\underset{\mathrm{I}}{\simeq}$ & $\underbrace{\infty}$ & & 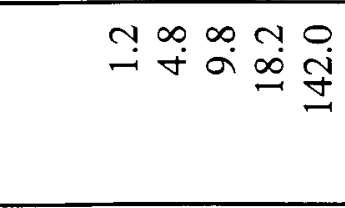 \\
\hline 旅 & $\stackrel{\circ}{\forall}$ & $\begin{array}{l}0 \\
\ddot{b}\end{array}$ & $\stackrel{\circ}{\circ}$ & & 웅웅 숭요 \\
\hline 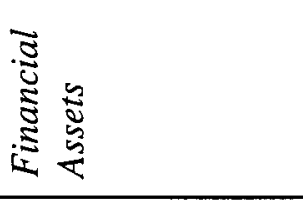 & $\ddot{b}$ & $\stackrel{\varphi}{=}$ & $\stackrel{\sim}{\sim}$ & & 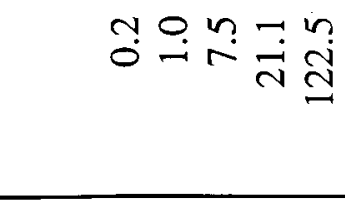 \\
\hline & $\equiv$ & 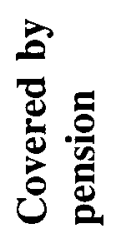 & 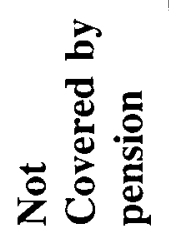 & $\bar{\psi}$ & 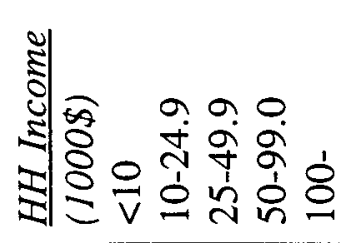 \\
\hline
\end{tabular}




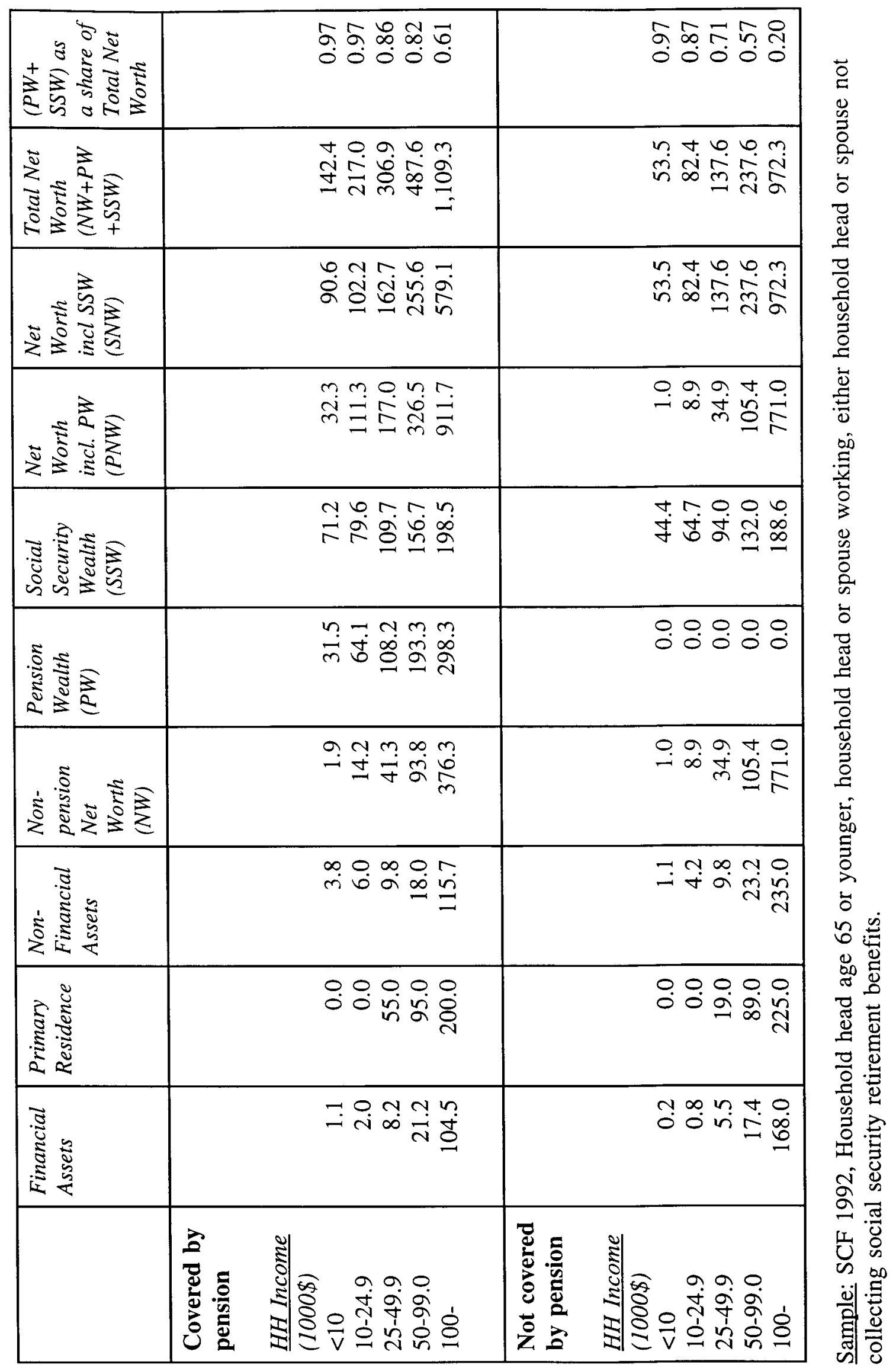


Table 4: Holdings and Distribution of Assets, Debts, and Income; by Percentiles of Net Worth Not Including Pension Wealth or Net Social Security Wealth; Households with Heads Aged Less than 65; 1992 SCF. All dollar figures are given in billions of 1992 dollars.

\begin{tabular}{|c|c|c|c|c|c|c|c|c|c|c|}
\hline \multirow[b]{3}{*}{ Item } & \multicolumn{10}{|c|}{ Percentile of the net worth distribution } \\
\hline & \multicolumn{2}{|c|}{ All households } & \multicolumn{2}{|c|}{0 to 89.9} & \multicolumn{2}{|l|}{90 to 99} & \multicolumn{2}{|c|}{99 to 99.5} & \multicolumn{2}{|c|}{99.5 to 100} \\
\hline & Holdings & $\begin{array}{c}\% \text { of } \\
\text { total }\end{array}$ & Holdings & $\begin{array}{cc}\% & \text { of } \\
\text { total }\end{array}$ & Holdings & $\begin{array}{cc}\% & \text { of } \\
\text { total }\end{array}$ & Holdings & $\begin{array}{cc}\% & \text { of } \\
\text { total }\end{array}$ & Holdings & $\begin{array}{l}\% \text { of } \\
\text { total }\end{array}$ \\
\hline \multirow[t]{2}{*}{ Assets } & $15,538.5$ & 100.0 & $5,910.9$ & 38.1 & $5,451.3$ & 35.1 & $1,030.6$ & 6.6 & $3,139.5$ & 20.2 \\
\hline & 977.9 & 0.0 & 297.6 & 2.0 & 565.5 & 1.7 & 154.7 & 0.7 & 277.2 & 1.4 \\
\hline \multirow[t]{2}{*}{ Princ. residence } & $5,220.3$ & 100.0 & $3,275.2$ & 62.7 & $1,574.1$ & 30.2 & 144.4 & 2.8 & 226.3 & 4.3 \\
\hline & 206.6 & 0.0 & 134.4 & 1.5 & 116.3 & 1.5 & 30.2 & 0.6 & 26.0 & 0.5 \\
\hline \multirow[t]{2}{*}{ Other real estate } & $2,187.5$ & 100.0 & 439.2 & 20.1 & 891.8 & 40.8 & 160.7 & 7.3 & 695.0 & 31.7 \\
\hline & 263.0 & 0.0 & 52.3 & 2.3 & 128.1 & 3.2 & 76.4 & 2.7 & 122.6 & 3.8 \\
\hline \multirow[t]{2}{*}{ Stocks } & $1,145.6$ & 100.0 & 218.2 & 19.1 & 478.3 & 41.7 & 111.4 & 9.7 & 337.2 & 29.4 \\
\hline & 135.7 & 0.0 & 23.6 & 2.6 & 77.3 & 3.4 & 44.2 & 3.3 & 56.4 & 3.8 \\
\hline \multirow[t]{2}{*}{ Bonds } & 522.5 & 100.0 & 53.0 & 10.1 & 227.3 & 43.5 & 96.4 & 18.4 & 145.5 & 27.9 \\
\hline & 76.0 & 0.0 & 10.7 & 1.9 & 51.2 & 5.5 & 40.8 & 6.4 & 31.2 & 6.3 \\
\hline \multirow[t]{2}{*}{ Trusts } & 208.6 & 100.0 & 34.4 & 16.5 & 82.6 & 39.6 & 10.9 & 5.2 & 80.5 & 38.6 \\
\hline & 39.6 & 0.0 & 8.8 & 3.5 & 24.1 & 6.9 & 7.7 & 3.2 & 24.1 & 6.8 \\
\hline \multirow[t]{2}{*}{ Life Insurance } & 344.7 & 100.0 & 188.1 & 54.7 & 131.8 & 38.1 & 8.9 & 2.6 & 15.9 & 4.6 \\
\hline & 44.0 & 0.0 & 15.4 & 6.2 & 38.4 & 6.7 & 3.3 & 1.0 & 3.2 & 1.0 \\
\hline \multirow[t]{2}{*}{ Checking accts } & 134.3 & 100.0 & 79.9 & 59.5 & 37.7 & 28.1 & 5.1 & 3.8 & 11.6 & 8.6 \\
\hline & 8.1 & 0.0 & 5.2 & 2.8 & 4.5 & 2.6 & 1.3 & 0.9 & 2.3 & 1.6 \\
\hline \multirow[t]{2}{*}{ Thrift accounts } & 616.3 & 100.0 & 235.1 & 38.2 & 319.6 & 51.9 & 29.2 & 4.7 & 32.4 & 5.3 \\
\hline & 64.3 & 0.0 & 23.7 & 4.0 & 51.4 & 4.7 & 21.2 & 3.4 & 12.7 & 2.0 \\
\hline \multirow[t]{2}{*}{ Other accounts } & $1,097.0$ & 100.0 & 465.1 & 42.4 & 434.7 & 39.6 & 73.6 & 6.7 & 123.4 & 11.2 \\
\hline & 70.1 & 0.0 & 33.2 & 2.5 & 46.0 & 2.6 & 25.4 & 2.2 & 31.5 & 2.7 \\
\hline \multirow[t]{2}{*}{ Businesses } & $2,967.9$ & 100.0 & 278.8 & 9.4 & 983.2 & 33.2 & 333.9 & 11.3 & $1,368.5$ & 46.0 \\
\hline & 363.0 & 0.0 & 47.1 & 1.6 & 188.7 & 3.9 & 80.8 & 2.2 & 204.3 & 4.4 \\
\hline Automobiles & 678.1 & 100.0 & 512.9 & 75.6 & 136.3 & 20.1 & 10.4 & 1.5 & 18.5 & 2.7 \\
\hline & 18.0 & 0.0 & 11.6 & 1.2 & 11.2 & 1.3 & 2.7 & 0.4 & 3.2 & 0.5 \\
\hline Other assets & 415.6 & 100.0 & 130.9 & 31.5 & 154.0 & 37.0 & 45.9 & 11.0 & 84.7 & 20.4 \\
\hline & 51.8 & 0.0 & 18.0 & 4.1 & 36.4 & 5.4 & 15.7 & 3.4 & 22.3 & 4.2 \\
\hline Pension wealth & $7,434.4$ & 100.0 & $5,829.3$ & 78.4 & $1,405.5$ & 18.9 & 116.8 & 1.6 & 82.6 & 1.1 \\
\hline (not incl in NW) & 380.9 & 100.0 & 402.6 & 3.6 & 294.0 & 3.5 & 117.3 & 1.6 & 53.5 & 0.7 \\
\hline Net SS wealth & $7,936.2$ & 100.0 & $6,679.3$ & 84.2 & $1,126.4$ & 14.2 & 67.2 & 0.8 & 63.2 & 0.8 \\
\hline (not incl in NW) & 77.4 & 100.0 & 66.4 & 0.3 & 29.2 & 0.3 & 5.0 & 0.1 & 4.3 & 0.1 \\
\hline PDV SS tax & $3,471.3$ & 100.0 & $3,038.0$ & 87.5 & 390.1 & 11.2 & 23.2 & 0.7 & 19.9 & 0.6 \\
\hline (not incl in NW) & 41.5 & 100.0 & 39.4 & 0.3 & 11.7 & 0.3 & 1.9 & 0.1 & 1.3 & 0.0 \\
\hline Liabilities & $3,178.8$ & 100.0 & $2,068.3$ & 65.1 & 813.1 & 25.6 & 74.1 & 2.3 & 222.7 & 7.0 \\
\hline & 142.9 & 0.0 & 88.6 & 2.1 & 74.3 & 1.7 & 27.6 & 0.8 & 34.0 & 1.0 \\
\hline Princ. res. debt & $2,101.4$ & 100.0 & $1,545.5$ & 73.6 & 474.6 & 22.6 & 33.2 & 1.6 & 48.0 & 2.3 \\
\hline & 83.3 & 0.0 & 70.6 & 2.0 & 44.3 & 1.8 & 10.9 & 0.5 & 6.8 & 0.3 \\
\hline Other $\mathrm{r} / \mathrm{e}$ debt & 583.8 & 100.0 & 125.4 & 21.5 & 272.2 & 46.6 & 33.0 & 5.6 & 153.1 & 26.2 \\
\hline & 74.0 & 0.0 & 21.6 & 3.1 & 41.0 & 3.9 & 19.6 & 2.7 & 30.8 & 4.0 \\
\hline Other debt & 493.5 & 100.0 & 397.4 & 80.5 & 66.3 & 13.4 & 8.0 & 1.6 & 21.7 & 4.4 \\
\hline & 22.3 & 0.0 & 19.3 & 2.1 & 10.4 & 1.9 & 3.0 & 0.6 & 5.4 & 1.0 \\
\hline NW w/o PW/NSSW & $12,359.7$ & 100.0 & $3,842.6$ & 31.1 & $4,638.2$ & 37.5 & 956.4 & 7.7 & $2,916.8$ & 23.6 \\
\hline & 880.4 & 0.0 & 227.4 & 1.9 & 517.2 & 1.8 & 134.8 & 0.7 & 266.1 & 1.7 \\
\hline Total income & $3,199.8$ & 100.0 & $2,237.5$ & 69.9 & 703.0 & 22.0 & 87.1 & 2.7 & 171.7 & 5.4 \\
\hline & 78.2 & 0.0 & 48.6 & 1.3 & 48.7 & 1.1 & 11.8 & 0.4 & 21.3 & 0.6 \\
\hline Memo items: & & & & & & & & & & \\
\hline Min net worth (T \$) & -325 & & -325 & & 268. & & $2,090.3$ & & $3,288.0$ & \\
\hline Num. of obs. & 3003 & & 2027. & & 531. & & 74.0 & & $371 . C$ & \\
\hline Wgtd num. units (M) & 74 & 4.8 & 67 & & 6. & & 0.4 & & 0.4 & \\
\hline
\end{tabular}


Table 5: Holdings and Distribution of Assets, Debts, and Income; by Percentiles of Net Worth Including Pension Wealth and Net Social Security Wealth; Households with Heads Aged Less than 65; 1992 SCF. All dollar figures are given in billions of $\mathbf{1 9 9 2}$ dollars.

\begin{tabular}{|c|c|c|c|c|c|c|c|c|c|c|}
\hline \multirow[b]{3}{*}{ Item } & \multicolumn{10}{|c|}{ Percentile of the net worth distribution } \\
\hline & \multicolumn{2}{|c|}{ All households } & \multicolumn{2}{|l|}{0 to 89.9} & \multicolumn{2}{|l|}{90 to 99} & \multicolumn{2}{|l|}{99 to 99.5} & \multicolumn{2}{|c|}{99.5 to 100} \\
\hline & Holdings & $\begin{array}{c}\% \text { of } \\
\text { total }\end{array}$ & Holdings & $\begin{array}{l}\% \text { of } \\
\text { total }\end{array}$ & Holdings & $\begin{array}{cc}\% & \text { of } \\
\text { total }\end{array}$ & Holdings & $\begin{array}{l}\% \text { of } \\
\text { total }\end{array}$ & Holdings & $\begin{array}{l}\% \text { of } \\
\text { total }\end{array}$ \\
\hline \multirow[t]{2}{*}{ Assets } & $30,909.1$ & 100.0 & $17,186.7$ & 55.6 & $8,929.3$ & 28.9 & $1,285.9$ & 4.2 & $3,500.7$ & 11.3 \\
\hline & $1,087.8$ & 0.0 & 477.1 & 1.2 & 552.5 & 0.9 & 159.0 & 0.4 & 268.2 & 0.8 \\
\hline \multirow[t]{2}{*}{ Princ. residence } & $5,220.3$ & 100.0 & $3,465.3$ & 66.4 & $1,394.6$ & 26.7 & 142.9 & 2.7 & 217.2 & 4.2 \\
\hline & 206.6 & 0.0 & 133.4 & 1.5 & 108.7 & 1.4 & 23.0 & 0.4 & 27.1 & 0.5 \\
\hline \multirow[t]{2}{*}{ Other real estate } & $2,187.5$ & 100.0 & 545.7 & 25.0 & 814.0 & 37.2 & 183.1 & 8.4 & 643.8 & 29.4 \\
\hline & 263.0 & 0.0 & 60.9 & 2.7 & 117.5 & 3.1 & 108.4 & 4.1 & 130.3 & 4.7 \\
\hline \multirow[t]{2}{*}{ Stocks } & $1,145.6$ & 100.0 & 268.7 & 23.6 & 427.3 & 37.3 & 110.6 & 9.6 & 338.6 & 29.5 \\
\hline & 135.7 & 0.0 & 25.1 & 3.2 & 86.4 & 4.3 & 44.0 & 3.7 & 64.9 & 3.9 \\
\hline \multirow[t]{2}{*}{ Bonds } & 522.5 & 100.0 & 81.6 & 15.6 & 204.8 & 39.2 & 91.0 & 17.4 & 144.8 & 27.7 \\
\hline & 76.0 & 0.0 & 15.8 & 3.0 & 67.2 & 8.1 & 36.7 & 6.6 & 28.0 & 5.2 \\
\hline \multirow[t]{2}{*}{ Trusts } & 208.6 & 100.0 & 47.7 & 22.9 & 72.9 & 34.9 & 8.0 & 3.8 & 79.8 & 38.3 \\
\hline & 39.6 & 0.0 & 9.4 & 4.2 & 26.0 & 7.5 & 8.4 & 3.5 & 24.0 & 6.8 \\
\hline \multirow[t]{2}{*}{ Life Insurance } & 344.7 & 100.0 & 202.4 & 58.8 & 118.4 & 34.3 & 8.8 & 2.5 & 15.1 & 4.4 \\
\hline & 44.0 & 0.0 & 16.5 & 6.6 & 37.7 & 6.9 & 2.8 & 0.8 & 3.2 & 1.0 \\
\hline \multirow[t]{2}{*}{ Checking accts } & 134.3 & 100.0 & 84.9 & 63.3 & 33.4 & 24.9 & 4.6 & 3.4 & 11.3 & 8.4 \\
\hline & 8.2 & 0.0 & 5.0 & 2.7 & 4.7 & 2.7 & 2.2 & 1.6 & 2.3 & 1.6 \\
\hline \multirow[t]{2}{*}{ Thrift accounts } & 616.3 & 100.0 & 213.0 & 34.6 & 320.6 & 52.0 & 44.1 & 7.2 & 38.6 & 6.2 \\
\hline & 64.3 & 0.0 & 19.5 & 4.0 & 52.6 & 5.1 & 31.2 & 3.9 & 20.1 & 3.1 \\
\hline \multirow[t]{2}{*}{ Other accounts } & $1,097.0$ & 100.0 & 546.9 & 49.8 & 368.9 & 33.6 & 60.9 & 5.6 & 120.0 & 10.9 \\
\hline & 70.1 & 0.0 & 40.5 & 3.0 & 49.5 & 3.2 & 22.5 & 2.0 & 32.3 & 2.8 \\
\hline \multirow[t]{2}{*}{ Businesses } & $2,967.0$ & 100.0 & 478.9 & 16.2 & 892.7 & 30.1 & 268.7 & 9.1 & $1,324.1$ & 44.5 \\
\hline & 363.0 & 0.0 & 75.0 & 2.8 & 190.2 & 3.8 & 95.2 & 3.0 & 227.0 & 5.1 \\
\hline Automobiles & 768.1 & 100.0 & 513.3 & 75.7 & 133.6 & 19.7 & 10.7 & 1.6 & 20.5 & 3.0 \\
\hline & 18.0 & 0.0 & 11.7 & 1.2 & 8.1 & 0.9 & 2.9 & 0.4 & 5.3 & 0.8 \\
\hline Other assets & $1,031.9$ & 100.0 & 361.2 & 35.0 & 469.6 & 45.5 & 80.6 & 7.8 & 120.3 & 11.7 \\
\hline & 91.8 & 0.0 & 35.0 & 3.0 & 69.1 & 4.1 & 37.5 & 3.4 & 28.3 & 2.6 \\
\hline Pension wealth & $7,434.4$ & 100.0 & $3,965.5$ & 53.4 & $2,820.7$ & 37.9 & 247.6 & 3.3 & 400.4 & 5.3 \\
\hline & 380.9 & 100.0 & 189.9 & 2.8 & 225.1 & 2.1 & 107.3 & 1.4 & 248.0 & 3.1 \\
\hline Net SS wealth & $7,936.2$ & 100.0 & $6,624.5$ & 83.5 & $1,178.3$ & 14.8 & 68.3 & 0.9 & 64.8 & 0.8 \\
\hline & 77.6 & 100.0 & 72.0 & 0.4 & 33.3 & 0.4 & 86.5 & 0.1 & 49.5 & 0.1 \\
\hline PDV SS tax & $3,471.3$ & 100.0 & $2,997.0$ & 86.3 & 432.1 & 12.4 & 22.0 & 0.6 & 20.1 & 0.6 \\
\hline & 41.9 & 100.0 & 40.2 & 0.4 & 13.8 & 0.4 & 27.5 & 0.1 & 16.1 & 0.0 \\
\hline Liabilities & $3,178.8$ & 100.0 & $2,109.4$ & 66.4 & 775.5 & 24.4 & 84.9 & 2.7 & 208.5 & 6.6 \\
\hline & 142.9 & 0.0 & 85.9 & 1.9 & 69.7 & 1.5 & 38.3 & 1.1 & 35.2 & 1.1 \\
\hline Princ. res. debt & $2,101.4$ & 100.0 & $1,564.8$ & 74.5 & 455.6 & 21.7 & 38.3 & 1.8 & 42.7 & 2.0 \\
\hline & 83.3 & 0.0 & 66.7 & 1.6 & 38.7 & 1.5 & 9.2 & 0.4 & 6.4 & 0.3 \\
\hline Other $\mathrm{r} / \mathrm{e} \mathrm{debt}$ & 583.8 & 100.0 & 152.4 & 26.1 & 249.4 & 42.7 & 39.3 & 6.7 & 142.5 & 24.4 \\
\hline & 74.0 & 0.0 & 23.6 & 3.6 & 41.5 & 4.0 & 32.8 & 4.9 & 31.8 & 5.1 \\
\hline Other debt & 493.5 & 100.0 & 392.2 & 79.5 & 70.5 & 14.3 & 7.3 & 1.5 & 23.3 & 4.7 \\
\hline & 22.3 & 0.0 & 19.5 & 1.8 & 7.6 & 1.3 & 2.8 & 0.6 & 6.1 & 1.2 \\
\hline NW w/ PW+NSSW & $27,730.3$ & 100.0 & $15,077.3$ & 54.4 & $8,153.7$ & 29.4 & $1,201.1$ & 4.3 & $3,292.2$ & 11.9 \\
\hline & 989.4 & 0.0 & 415.8 & 1.2 & 510.5 & 0.9 & 134.2 & 0.4 & 256.0 & 0.8 \\
\hline Total income & $3,200.0$ & 100.0 & $2,236.9$ & 69.1 & 708.1 & 22.1 & 76.8 & 2.4 & 177.6 & 5.6 \\
\hline & 78.2 & 0.0 & 47.1 & 1.1 & 39.8 & 0.9 & 12.8 & 0.4 & 23.3 & 0.7 \\
\hline Memo items: & & & & & & & & & & \\
\hline Min net worth (T \$) & -89 & 9.5 & -89.5 & & 673.1 & & $1,972.2$ & & $3,314.9$ & \\
\hline Num. of obs. & 3003 & 3.0 & 2104 & & 472.0 & & 70.0 & & 357.0 & \\
\hline Wgtd num. units (M) & & 4.8 & 67.3 & & 6.8 & & 0.4 & & 0.4 & \\
\hline
\end{tabular}


Assets: All types of assets.

Principal residence: The residence that the survey respondent considered his or her principal residence.

Other real estate: All other types of real estate except those owned through a business.

Stocks: All types of stock and stock mutual funds (including "balanced" funds), including those held through an IRA or Keogh, but not those held through a thrift account.

Bonds: All types of bonds except savings bonds, and bond mutual funds, including those held through an IRA or Keogh, but not those held through a thrift account.

Trusts: All trusts with an equity interest, managed investment accounts, and private annuities.

Life Insurance: Cash value of whole life and universal life insurance.

Checking accounts: All types of standard checking accounts and share draft accounts.

Thrift accounts: Pension and other retirement accounts from a current job from which withdrawals can be made or loans taken out.

Other accounts: Money market and savings accounts, certificates of deposit, and savings bonds.

Businesses: All types of businesses except corporations with publicly-traded stock.

Automobiles: Automobiles, trucks, motorcycles, boats, air planes, and other vehicles not owned by a business.

Other assets: Includes all other assets (antiques, paintings, jewelry, metals, futures contracts, oil leases, etc.).

Pension wealth: the present value of future defined-benefit accounts and defined contribution plans other than 401(k)-type accounts; as defined elsewhere in this paper.

Net Social Security wealth: present discounted value of future Social Security retirement benefits net of employees' contributions; as defined elsewhere in this paper.

Present discounted value of Social Security taxes: Discounted sum of employees' share of future

Social Security taxes; as defined elsewhere in this paper.

Liabilities: All types of debt.

Principal residence debt: All mortgages and home equity lines associated a principal residence.

Other real estate debt: All other debt secured by real estate.

Other debt: All other types of debt (installment credit, credit cards, etc.).

Net worth: Assets minus liabilities.

Total income: Total household income from all sources in the year preceding the survey.

Standard errors are given in italics below each estimate. 
Table 6: $\quad$ List of Variables

\begin{tabular}{|c|c|}
\hline Variable name & Variable description \\
\hline LNW & Logarithm of net worth \\
\hline HAVEDB & Indicator variable for having a defined benefit plan \\
\hline LDBW & $\begin{array}{l}\text { Logarithm of wealth in defined benefit plan, adjusted for time until } \\
\text { retirement and knowledge of expected benefits }\end{array}$ \\
\hline DKDBW & $\begin{array}{l}\text { Indicator variable for not knowing expected benefits from defined } \\
\text { benefit plan. }\end{array}$ \\
\hline HAVEDC & Indicator variable for having a defined contribution plan \\
\hline LDCW & Logarithm of wealth accumulated in defined contribution plan \\
\hline LSSECN & Logarithm of Social Security wealth \\
\hline HIRA & Indicator variable for having an IRA \\
\hline LIRA & Logarithm of wealth accumulated in IRA \\
\hline HIRAL & $\begin{array}{l}\text { Indicator variable for having an IRA with account balance } 13,500 \text { or } \\
\text { less }\end{array}$ \\
\hline LIRAL & $\begin{array}{l}\text { Logarithm of wealth accumulated in IRA with account balance } 13,500 \\
\text { or less }\end{array}$ \\
\hline HIRAH & $\begin{array}{l}\text { Indicator variable for having an IRA with account balance more than } \\
\$ 13,500\end{array}$ \\
\hline LIRAH & $\begin{array}{l}\text { Logarithm of wealth accumulated in IRA with account balance more } \\
\text { than } \$ 13,500\end{array}$ \\
\hline LHHINC & Logarithm of household income \\
\hline AGE & Age in years of household head \\
\hline EDUC & Years of education of household head \\
\hline MARRIED & Indicator variable for married/living with a partner \\
\hline KIDS & Number of children \\
\hline HOMEOWN & Indicator variable for owning home \\
\hline
\end{tabular}


Table 6: (cont) List of Variables

\begin{tabular}{|c|c|}
\hline Variable name & Variable description \\
\hline HREALEST & Indicator variable for owning real estate other than a vacation home \\
\hline HBUS & Indicator variable for owning a business \\
\hline NOSAVE & Indicator variable for not saving \\
\hline NOREGSAV & Indicator variable for saving, but not regularly \\
\hline REGSAVE & Indicator variable for saving regularly \\
\hline SSADQI & $\begin{array}{l}\text { Index ranging from } 0 \text { to } 1 \text { describing the adequacy of retirement } \\
\text { income from Social Security and pensions: } 0=\text { totally inadequate and } \\
1=\text { very satisfactory }\end{array}$ \\
\hline FINOBL & $\begin{array}{l}\text { Indicator variable if household have any foreseeable major financial } \\
\text { obligations }\end{array}$ \\
\hline HORIZON & $\begin{array}{l}\text { Household's planning horizon: } 1=\text { next few months; } 2=\text { next year; } \\
3=\text { next few years; } 4=\text { next } 5-10 \text { years; and } 5=\text { longer than } 10 \text { years }\end{array}$ \\
\hline NORINCN & Indicator variable for household income normal \\
\hline NORINCL & Indicator variable for household income lower than normal \\
\hline NORINCH & Indicator variable for household income higher than normal \\
\hline
\end{tabular}


Table 7: $\quad$ Effect of pension and Social Security wealth on net worth, 1992: OLS and robust regression, household head age 35-60

(standard errors in parentheses)

\begin{tabular}{|c|c|c|c|c|}
\hline & Ol & & Rol & \\
\hline & (1) & (2) & (3) & (4) \\
\hline HAVEDB & -0.37 & -0.37 & -0.29 & -0.29 \\
\hline & $(0.20)$ & $(0.20)$ & $(0.20)$ & $(0.20)$ \\
\hline LDBW & 0.02 & 0.02 & 0.02 & 0.02 \\
\hline & $(0.02)$ & $(0.02)$ & $(0.02)$ & $(0.02)$ \\
\hline DKDBW & 0.25 & 0.25 & 0.26 & 0.26 \\
\hline & $(0.19)$ & $(0.19)$ & $(0.19)$ & $(0.19)$ \\
\hline HAVEDC & -0.38 & -0.39 & -0.42 & -0.43 \\
\hline & $(0.36)$ & $(0.36)$ & $(0.33)$ & $(0.33)$ \\
\hline LDCW & 0.01 & 0.01 & 0.01 & 0.01 \\
\hline & $(0.03)$ & $(0.03)$ & $(0.03)$ & $(0.03)$ \\
\hline LSSECN & -0.04 & -0.04 & -0.05 & -0.05 \\
\hline & $(0.03)$ & $(0.03)$ & $(0.03)$ & $(0.03)$ \\
\hline HIRA & -1.38 & & -0.78 & \\
\hline & $(0.42)$ & & $(0.36)$ & \\
\hline LIRA & 0.20 & & 0.13 & \\
\hline HIR AH & $(0.04)$ & & $(0.04)$ & 176 \\
\hline M" & & $(1.01)$ & & $(0.86)$ \\
\hline LIRAH & & 0.32 & & 0.22 \\
\hline & & $(0.09)$ & & $(0.08)$ \\
\hline HIRAL & & -0.76 & & -0.88 \\
\hline & & $(0.78)$ & & $(0.66)$ \\
\hline LIRAL & & 0.13 & & 0.15 \\
\hline & & $(0.09)$ & & $(0.08)$ \\
\hline LHHINC & $\begin{array}{r}0.45 \\
(0.05)\end{array}$ & $\begin{array}{r}0.45 \\
(0.05)\end{array}$ & $\begin{array}{r}0.76 \\
(0.04)\end{array}$ & $\begin{array}{r}0.76 \\
(0.04)\end{array}$ \\
\hline & 0.04 & $\begin{array}{r}(0.05) \\
0.04\end{array}$ & $\begin{array}{r}(0.04) \\
0.04\end{array}$ & $(0.04)$ \\
\hline AGE & 0.04 & 0.04 & & 0.04 \\
\hline & $(0.01)$ & $(0.01)$ & $(0.01)$ & $(0.01)$ \\
\hline EDUC & 0.08 & 0.08 & 0.05 & 0.05 \\
\hline & $(0.02)$ & $(0.02)$ & $(0.02)$ & $(0.02)$ \\
\hline MARRIED & 0.02 & 0.02 & -0.16 & -0.16 \\
\hline & $(0.10)$ & $(0.10)$ & $(0.10)$ & $(0.10)$ \\
\hline KIDS & 0.00 & 0.00 & 0.00 & 0.00 \\
\hline & $(0.03)$ & $(0.03)$ & $(0.02)$ & $(0.02)$ \\
\hline
\end{tabular}


Table 7: (continued)

\begin{tabular}{|c|c|c|c|c|}
\hline & \multicolumn{2}{|c|}{ OLS } & \multicolumn{2}{|c|}{ Robust } \\
\hline & (1) & (2) & (3) & (4) \\
\hline HOMEOWN & 1.21 & 1.21 & 1.14 & 1.14 \\
\hline & $(0.12)$ & $(0.12)$ & $(0.09)$ & $(0.09)$ \\
\hline HREALEST & 1.27 & 1.28 & 1.00 & 1.01 \\
\hline & $(0.16)$ & $(0.16)$ & $(0.13)$ & $(0.13)$ \\
\hline HAVEBUS & 1.32 & 1.32 & 0.95 & 0.96 \\
\hline & $(0.13)$ & $(0.13)$ & $(0.12)$ & $(0.12)$ \\
\hline NOREGSAV & 0.05 & 0.05 & 0.09 & 0.08 \\
\hline & $(0.13)$ & $(0.13)$ & $(0.10)$ & $(0.11)$ \\
\hline REGSAVE & 0.28 & 0.28 & 0.27 & 0.26 \\
\hline & (0.13) & $(0.13)$ & $(0.10)$ & $(0.10)$ \\
\hline SSADQI & 0.12 & 0.13 & 0.01 & 0.02 \\
\hline & $(0.14)$ & $(0.14)$ & $(0.12)$ & $(0.12)$ \\
\hline FINOBL & 0.11 & 0.11 & 0.07 & 0.06 \\
\hline & $(0.08)$ & $(0.08)$ & $(0.07)$ & $(0.07)$ \\
\hline HORIZON & 0.04 & 0.04 & 0.04 & 0.04 \\
\hline & $(0.03)$ & $(0.03)$ & $(0.03)$ & $(0.03)$ \\
\hline NORINCL & 0.40 & 0.39 & 0.32 & 0.32 \\
\hline & $(0.12)$ & $(0.12)$ & $(0.11)$ & $(0.11)$ \\
\hline NORINCH & -0.03 & -0.03 & -0.07 & -0.07 \\
\hline & $(0.14)$ & $(0.14)$ & $(0.12)$ & $(0.12)$ \\
\hline CONSTANT & 2.34 & 2.41 & -0.34 & -0.27 \\
\hline & $(0.60)$ & $(0.59)$ & $(0.56)$ & $(0.56)$ \\
\hline Adj R-sq & 0.61 & 0.61 & & \\
\hline Num Obs & 949 & 949 & 949 & 949 \\
\hline
\end{tabular}

Source: 1992 Survey of Consumer Fiances 


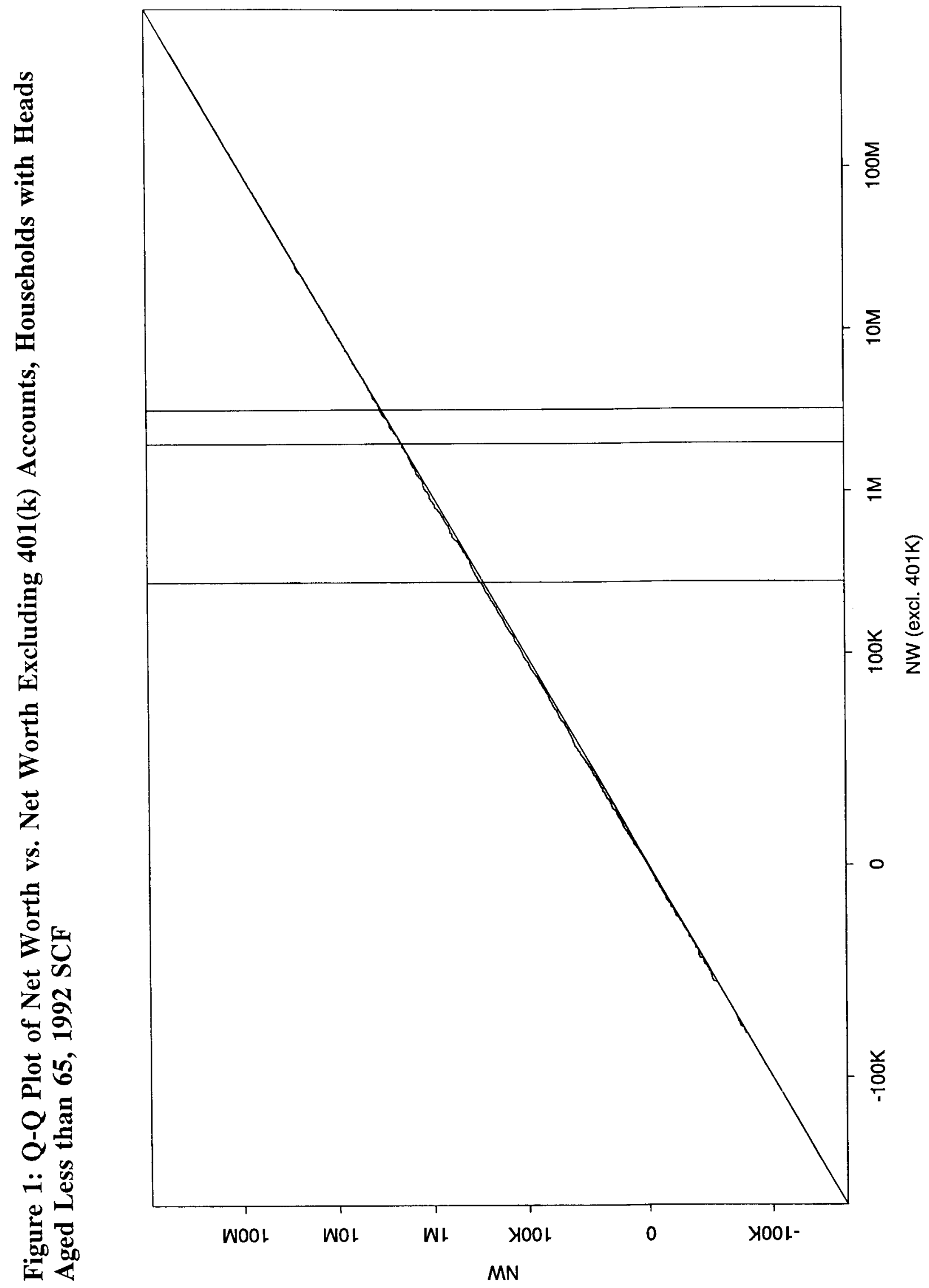




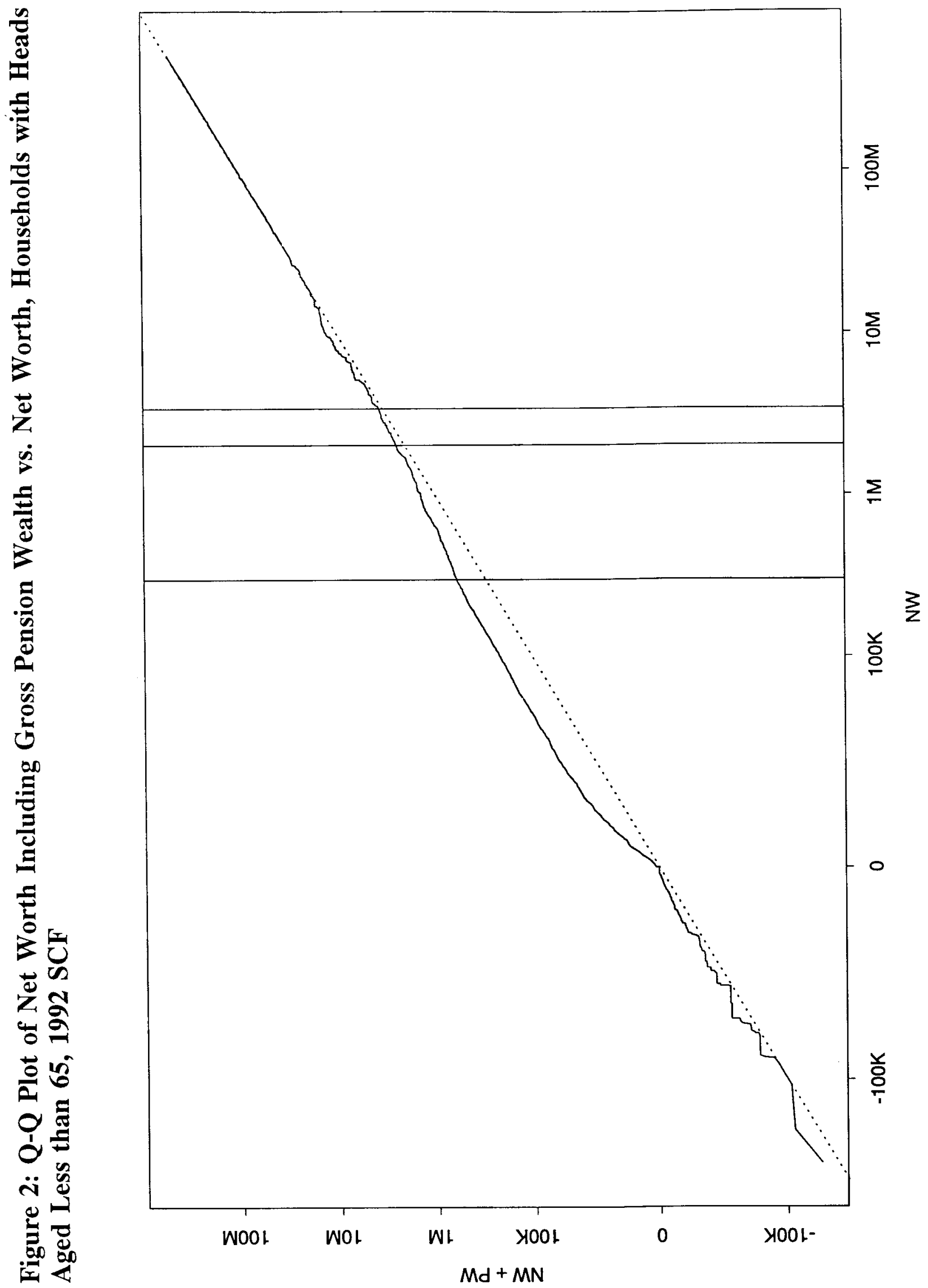



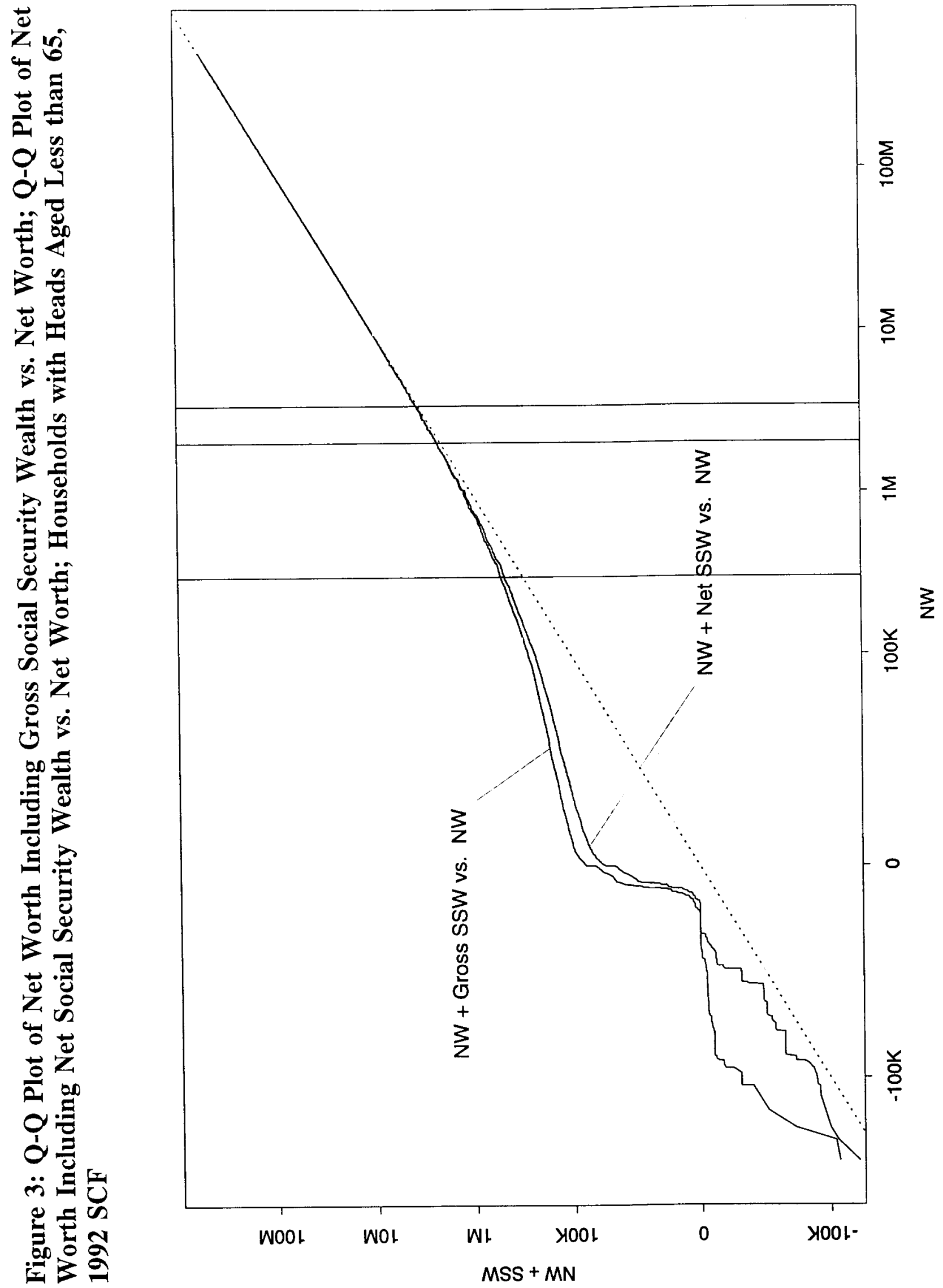

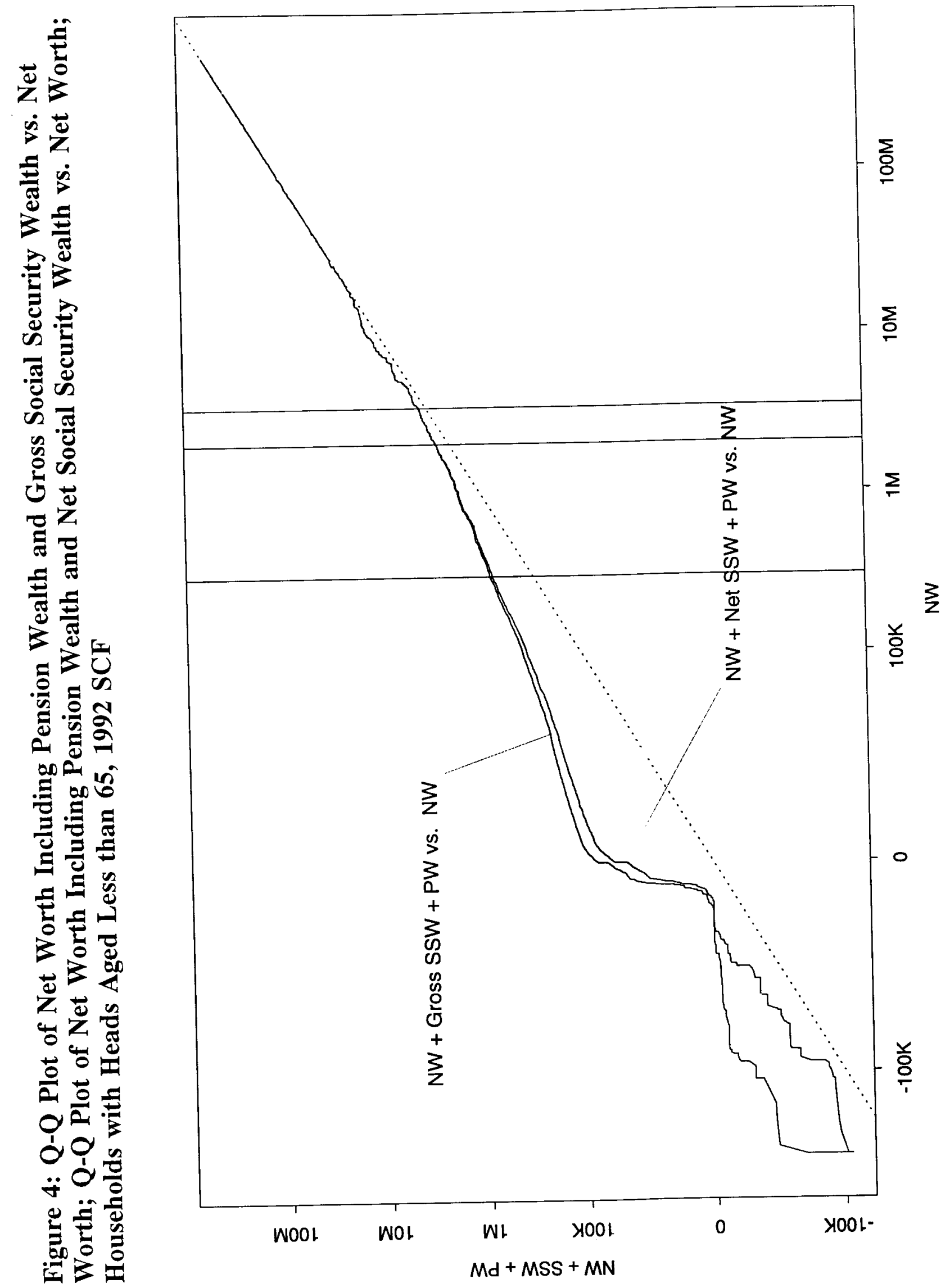


\section{Appendix}

This appendix describes how the earnings profile used to compute pension and Social Security benefits is constructed. The SCF collects information on current and past labor market participation as well as plans for future work for respondents as well as for spouses. From these reports, work histories are constructed from age 18 until expected retirement age for each person in the sample. For each year of ages these work histories indicate whether the individual worked and whether the work was full-time or part-time. For the current job and the longest prior job, the SCF collects information on earnings, industry and occupation, and the year the individual started and ended (or expects to end) the job. The earnings profile is an extrapolation over the work history of earnings from these two jobs.

The key inputs to this extrapolation are observed from wage equations estimated using 1992 CPS data at the 3-digit occupation level. ${ }^{1}$ The dependent variable in each model is the $\log$ of annualized wages and the explanatory variables include a spline in age, indicator variables for part-time, self-employment, race, and levels of education. The estimated coefficients from these wage equations are linked to the SCF data by 3-digit occupation code.

Using these estimates, wages are imputed for the years of the longest past job and the current job for each individual in the sample. The constant term in the model is adjusted so that the estimated and actual values coincide for the known points for the current and past jobs. Wages earned prior to the longest past job are assumed to follow the profile for the past job and wages earned after the current job are assumed to follow the current profile. For individuals without a current job but with future expected labor force participation, the wage profile for the past job is used.

When the current job immediately follows the longest prior job, there is no gap between the profiles. For cases where there is intervening employment, there are general possible extensions. One possibility is to assume that an individual follows the profile for the longest prior job until starting the current job. In many cases, this implies a sharp shift in the profile for a given individual at the date of starting the current job. There is a similar

\footnotetext{
${ }^{1}$ When too few observations are available to obtain estimates at this level of detail, the estimation is done at the 2-digit level.
} 
discontinuity if the current job information is projected backwards. Because we have no information to judge the relative importance of these jobs, we interpolate between the wage at the start of the current job. In years where the person has worked part-time, we assume that the wage is half of the full-time rate. All wage estimates are assumed to be in real terms, and no adjustments are made to account for secular movements in real wages.

The wage profile is then used to estimate pension and Social Security benefits. Respondents can report their expected pension benefit either as an amount or as a percentage of final pay. In the case an amount is reported, this is used directly in the present value calculation. If the benefit is reported as a percentage of final pay, the estimated wage profile is used to determine the earnings at the date the respondent plans to leave the current job. This will ignore pension benefits from any future jobs. Social Security benefits are determined using the estimated earnings profile. The profile together with reported number of years worked is the input in an algorithm used to calculate Social Security benefits. 